\title{
OS COMPLEXOS AGROINDUSTRIAIS NOS MUNICÍPIOS DE RIO VERDE E QUIRINÓPOLIS-GO
}

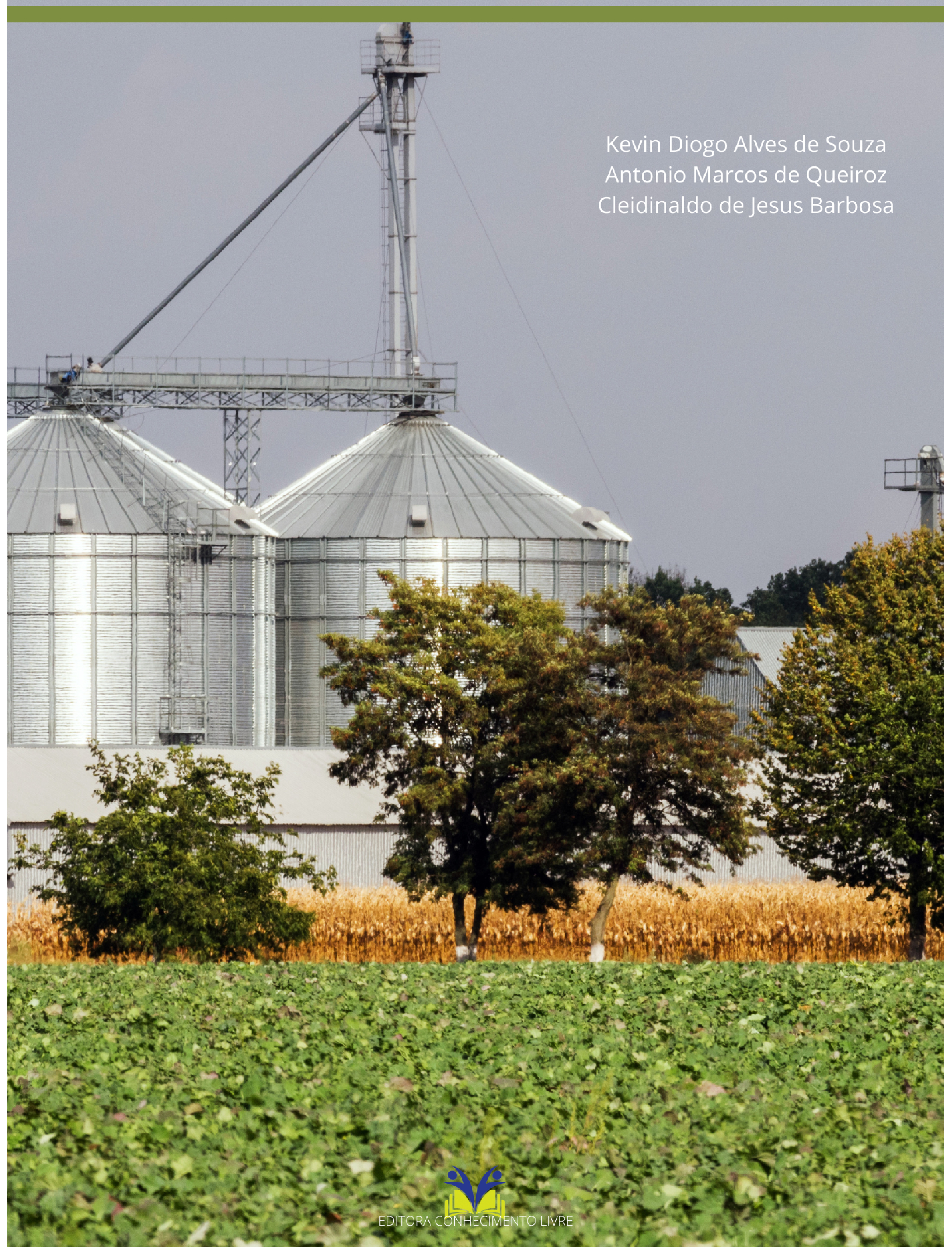


Kevin Diogo Alves de Souza

Antonio Marcos de Queiroz

Cleidinaldo de Jesus Barbosa

OS COMPLEXOS AGROINDUSTRIAIS NOS MUNICÍPIOS DE RIO VERDE E QUIRINÓPOLIS-GO

$1^{\text {a }}$ ed.

Piracanjuba-GO

Editora Conhecimento Livre

Piracanjuba-GO 
$1^{\mathrm{a}} \mathrm{ed}$

\section{Dados Internacionais de Catalogação na Publicação (CIP)}

\section{Souza, Kevin Diogo Alves de \\ S719O OS COMPLEXOS AGROINDUSTRIAIS NOS MUNICÍPIOS DE RIO VERDE E QUIRINÓPOLIS-GO}

/ Kevin Diogo Alves de Souza. Antonio Marcos de Queiroz. Cleidinaldo de Jesus Barbosa. Piracanjuba-GO

Editora Conhecimento Livre, 2021

49 f.: il

DOI: $10.37423 / 2021 . e d c 1355$

ISBN: 978-65-89955-75-7

Modo de acesso: World Wide Web

Incluir Bibliografia

1. complexos-agroindustriais 2. goiás 3. rio-verde-e-quirinópolis I. Souza, Kevin Diogo Alves de II. Queiroz, Antonio Marcos de III. Barbosa, Cleidinaldo de Jesus IV. Título 


\title{
EDITORA CONHECIMENTO LIVRE
}

\section{Corpo Editorial}

\author{
Dr. João Luís Ribeiro Ulhôa \\ Dra. Eyde Cristianne Saraiva-Bonatto \\ Dr. Anderson Reis de Sousa \\ MSc. Frederico Celestino Barbosa \\ MSc. Carlos Eduardo de Oliveira Gontijo
}

$\underline{\text { MSc. Plínio Ferreira Pires }}$

Editora Conhecimento Livre

Piracanjuba-GO 
OS COMPLEXOS AGROINDUSTRIAIS NOS MUNICÍPIOS DE RIO VERDE E QUIRINÓPOLISGO

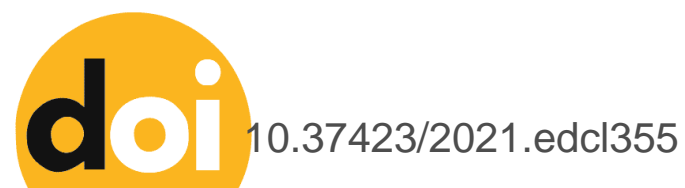

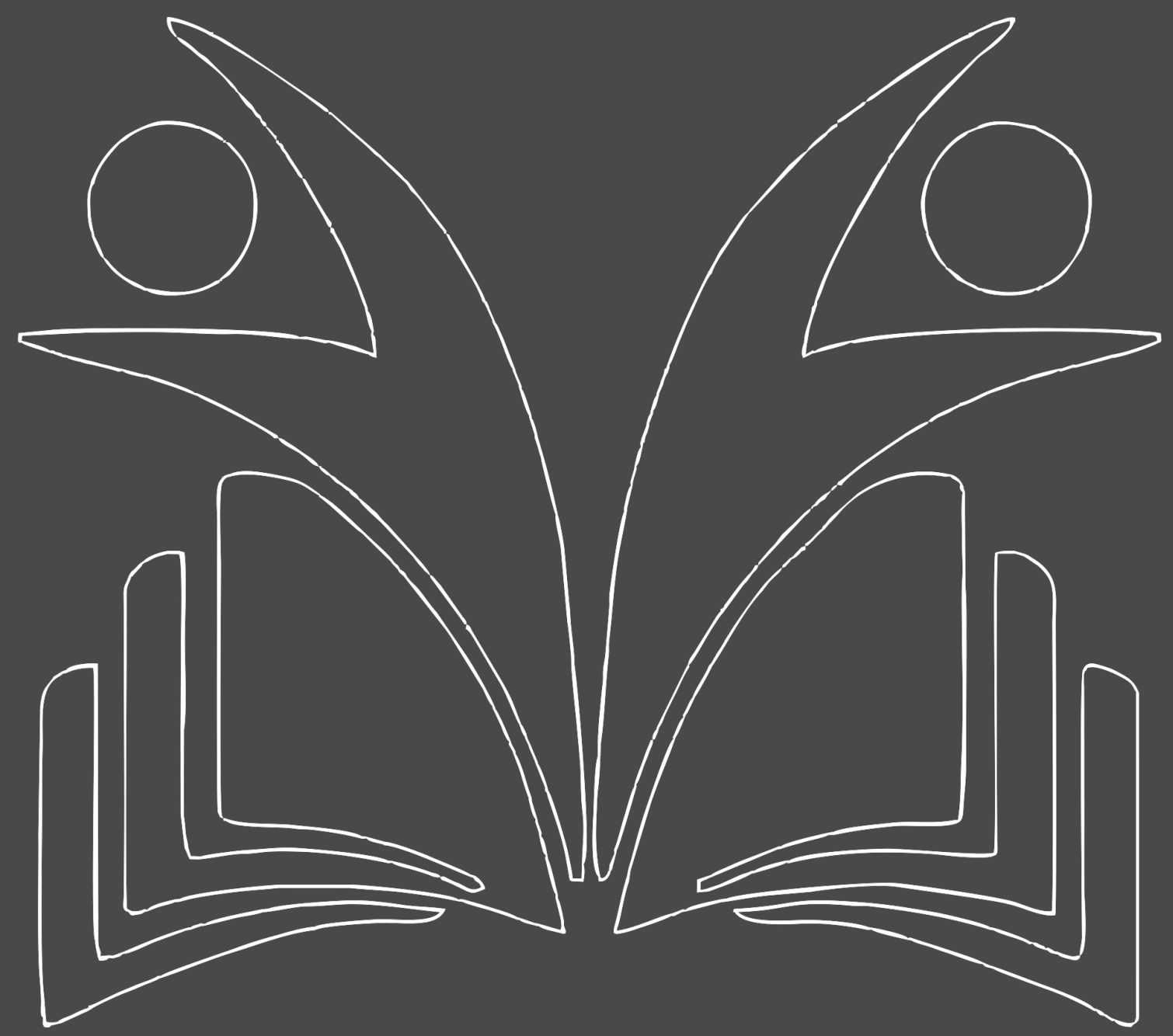


Homenagem do autor Kevin...

Aos meus pais Anderlei e Adriana Aos meus avós Valteci e Waldivina Que são meus alicerces nesta vida e sempre estiveram comigo na jornada desafiadora pela busca do conhecimento. 
Resumo: No ano de 2015, atingiu-se a quantidade de 7,3 bilhões de pessoas habitando a Terra e, segundo um estudo do Instituto Francês de Estudos Demográficos - INED (2015), no ano de 2050, chegaremos à incrível marca de 10 bilhões de habitantes no mundo. A atividade agropecuária desempenha e continuará desempenhando um papel crucial neste processo, sendo a chave para que tal crescimento populacional seja viável. Eficiente, moderno e competitivo, o agronegócio brasileiro é uma atividade rentável, segura e próspera, desempenhando neste contexto um papel de extrema relevância na economia como um todo do país, e do mundo. Em nível nacional, o estado de Goiás apresenta, neste contexto, uma importante e representativa participação no agronegócio brasileiro. O objetivo deste trabalho é analisar a influência dos complexos agroindustriais nos municípios de Rio Verde e Quirinópolis, considerados por terem tradição agropecuária. Foram utilizados dados históricos do Instituto Brasileiro de Geografia e Estatística (IBGE), Instituto Mauro Borges (IMB), Ministério da Agricultura, Pecuária e Abastecimento (MAPA) e Confederação da Agricultura e Pecuária do Brasil (CNA) como fontes da pesquisa qualitativa. Os resultados mostram o surgimento e evolução dos complexos agroindustriais da soja, milho e cana, que tiveram relevante apoio do Estado, e suas influências no crescimento do PIB municipal, renda per capita, empregos formais de forma direta e indireta, e IDH municipal em Rio Verde e Quirinópolis. Conclui-se que tais complexos agroindustriais como um todo influenciam de forma positiva na geração de riqueza a toda cadeia envolvida, promovem o crescimento do emprego diretamente e indiretamente, além de elevar a renda per capita e IDH municipal independentemente da cultura predominante.

Palavras-chave: Agronegócio; Complexo Agroindustrial; Agronegócio em Goiás 


\section{Lista de Tabelas}

Tabela 1: Brasil: índices simples da utilização de insumos básicos pela agricultura (1967 - 1975) 18

Tabela 2: Os dez maiores municípios da indústria goiana, segundo participação nas vendas industriais - anos selecionados 25

Tabela 3: Estado de Goiás: Estoque e participação de empregos formais do agronegócio (2014 2015) 26

Tabela

4: $\quad$ Principais produtos

exportados

em

Goiás

2016. 


\section{Lista de Figuras}

Figura 1: Esquema do Complexo Agroindustrial .14

Figura 2: Processo de Modernização da Agricultura 17

Figura 3: Divisão regional do Estado de Goiás - Plano de Desenvolvimento Econômico de Goiás (19611965)

Figura 4: Estado de Goiás - número de estabelecimentos agrícolas com tratores, fertilizantes e defensivos agrícolas $(1975$ - 2006) 23

Figura 5: Estado de Goiás - Evolução da população urbana, rural e total (1950 - 2010) 24

Figura 6: Estado de Goiás - Evolução da produção em toneladas (1974 - 2016) 27

Figura 7: Estado de Goiás - Participação dos cinco maiores setores nas exportações do agronegócio (2009 a 2015) 28

Figura 8: Mapa do Município de Rio Verde - GO 31

Figura 9: Exportação de milho: Sudoeste de Goiás, Rio Verde (1997 - 2016) 32

Figura 10: Exportação de soja (mesmo triturada), Farelo de soja e Óleos de soja, Goiás, Sudoeste de Goiás e Rio Verde (1997 - 2016) 33

Figura 11: Goiás, Sudoeste de Goiás: número de tratores e utilização de Defensivos e Fertilizantes agrícolas por estabelecimentos agropecuários (1975 - 2006) 37

Figura 12: Mapa do Município de Quirinópolis - GO 35

Figura 13: Área plantada de soja, milho e cana em Quirinópolis em hectares (1998 - 2016).......36

Figura 14: Área plantada com cana-de-açúcar por microrregião pertencente à mesorregião Sul de Goiás em hectares (2006 - 2016)

Figura 15: Valor Adicionado Bruto por atividade econômica no PIB de Rio Verde (1999 - 2014) $\mathrm{R} \$ 1.000$ 38

Figura 16: Valor Adicionado Bruto por atividade econômica no PIB de Quirinópolis (1999 - 2014) - R\$ 1.000 38 


\section{Os Complexos Agroindustriais Nos Municípios De Rio Verde E Quirinópolis-Go}

Figura 17: Renda Média Domiciliar per Capita de Rio Verde e Quirinópolis (1991 - 2010) 39

Figura 18: Pessoas ocupadas em Rio Verde e Quirinópolis (2006 - 2012) 39

Figura 19: Índice de Desenvolvimento Humano Municipal (1991 - 2010) 


\section{Sumário}

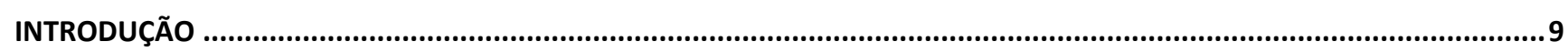

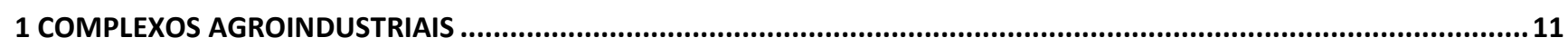

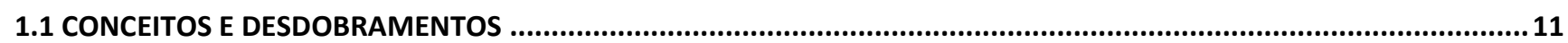

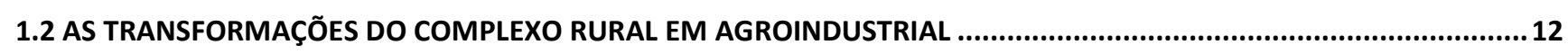

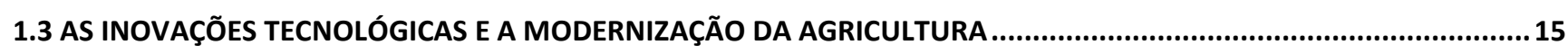

1.4 O COMPLEXO AGROINDUSTRIAL E O DESENVOLVIMENTO ECONÔMICO ..................................................................18

2 PANORAMA DOS COMPLEXOS AGROINDUSTRIAIS EM GOIÁS ............................................................................19

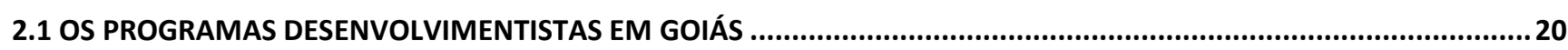

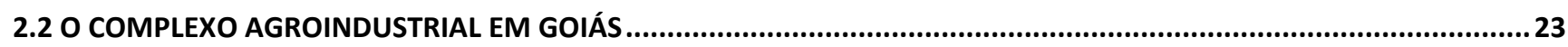

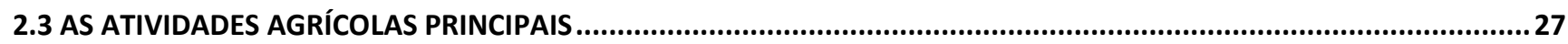

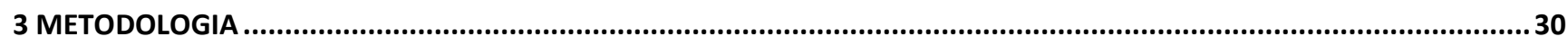

4 A INFLUÊNCIA DOS COMPLEXOS AGROINDUSTRIAIS EM RIO VERDE E QUIRINÓPOLIS ................................................30

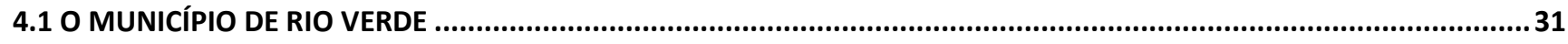

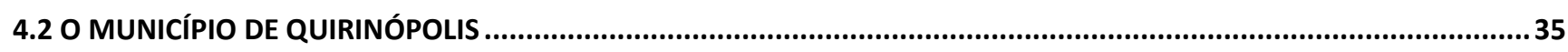

4.3 VALOR ADICIONADO BRUTO DA AGROPECUÁRIA, RENDA MÉDIA PER CAPITA, EMPREGO E IDH-M ..........................37

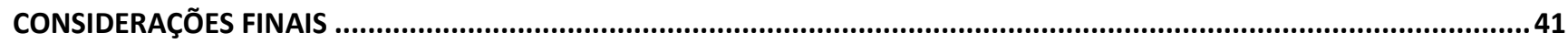

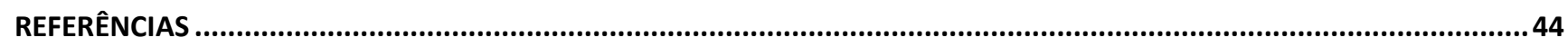




\section{INTRODUÇÃO}

De clima tropical e diversificado, energia solar abundante, com chuvas regulares e quase $13 \%$ de toda a água doce disponível no planeta, o Brasil possui 388 milhões de hectares de terras férteis e de alta produtividade, dos quais 106 milhões ainda não foram explorados, de acordo com o Ministério de Agricultura e Pecuária - MAPA (2005). Esses fatores fazem do país um lugar de vocação natural para a agropecuária e todos os negócios relacionados a suas cadeias produtivas.

De acordo com o Centro de Estudos Avançados em Economia Aplicada - CEPEA (2016), no ano de 2015, o agronegócio, com as atividades de insumos, agropecuária, indústria e distribuição, representou 21,5\% do PIB brasileiro. A Confederação da Agricultura e Pecuária do Brasil - CNA (2016) contabilizou que, no final de 2016, o agronegócio tenha crescido de 2,5 a 3\%, frente a queda de mais de 3\% no PIB Nacional, razão pelo qual, então, o agronegócio é considerado hoje a principal locomotiva da economia brasileira.

Além de tamanha relevância no PIB, o agronegócio é responsável por cerca de $48 \%$ das exportações brasileiras, sendo alavancado principalmente pelas exportações do complexo da soja, setor de cárneos e setor sucroalcooleiro (CNA, 2016). Vale ressaltar que o país lidera o ranking de vendas externas de soja e, segundo a Organização para a Cooperação e Desenvolvimento Econômico em conjunto com a Organização das Nações Unidas para a Alimentação e a Agricultura (2015), o Brasil será o maior produtor mundial de alimentos já na próxima década.

Levando em consideração o mercado de trabalho brasileiro, de acordo com estudos da CNA (2016) e do CEPEA (2016) o agronegócio, em 2015, empregava cerca de 19 milhões de trabalhadores e, em 2016, gerou mais 75 mil novos empregos, que representa em torno de $20 \%$ da população economicamente ativa, frente ao aumento do desemprego no Brasil, que no mesmo período, extinguiu quase 790 mil postos de trabalho nos demais setores da economia.

O Estado de Goiás apresenta, neste contexto, uma importante participação no agronegócio brasileiro. Chegando a uma marca de $\mathrm{R} \$ 15.645$ milhões a preços correntes em 2014, a agropecuária atinge uma representatividade de 10,7\% do PIB goiano, segundo estudo do Instituto Mauro Borges - IMB (2016).

De acordo com o IMB (2016), Goiás se encontra em quarto colocado na produção de grãos (cerca de 16,93 milhões de toneladas anualmente produzidas), com uma representatividade de quase $10 \%$ da produção total brasileira, sendo que o principal grão produzido é a soja, com produção de 10 milhões de toneladas por ano, seguido pelo milho e sorgo. No que se refere ao mercado de trabalho, o 
agronegócio foi responsável por 238.461 postos de trabalho gerados em Goiás no ano de 2015, número que representa a parcela significativa de $15,9 \%$ do total de empregos gerados no estado.

Rio Verde, sendo a 4ạ maior potência do estado, tem como pilar da sua economia o agronegócio, que representa mais de $16 \%$ dos postos de trabalhos da economia municipal. De acordo com o IMB (2016), o município ocupa a segunda posição na produção de grãos em Goiás e detém o 10 maior valor adicionado da agropecuária. A soja, neste contexto, possui uma grande participação na economia do município e representa quase metade do fluxo total de grãos para o mercado exterior, seguido do milho, que representa $37,13 \%$ deste total.

O município de Quirinópolis, cidade localizada no sul goiano, por outro lado, vem de uma recente contração na produção de grãos, substituída pela expansão do setor sucroalcooleiro a partir de 2004, e chega em 2016 com mais de 66 mil hectares utilizados exclusivamente para o cultivo da cana-deaçúcar, que vem causando mudanças significativas na economia da região, fazendo Quirinópolis ocupar hoje lugar de destaque no setor sucroalcooleiro goiano, se colocando como o maior produtor de cana do estado, segundo o IMB (2016).

Levando em consideração os dados apresentados, estudar a fundo o Complexo Agroindustrial nos municípios de Rio Verde e Quirinópolis tornam-se capazes de ter uma maior compreensão do agronegócio em Goiás devido a importância dos municípios para o setor, para a região sudoeste e sul do estado, na produção de grãos e cana-de-açúcar e de saber quais as diferentes influências do agronegócio no crescimento e desenvolvimento de ambos os municípios.

Sendo assim, o principal objetivo deste trabalho analisar a influência econômica destes Complexos Agroindustriais que se estabeleceram nos municípios de Rio Verde e Quirinópolis, e os impactos sociais decorrentes, com a hipótese que independentemente do complexo estabelecido e da atividade agrícola predominante, a atividade agropecuária traz efeitos positivos no âmbito econômico e social para os municípios analisados. Para isso, é importante que seja compreendido as transformações que ocorreram no setor, que deram origem a estas estruturas complexas e se desenvolveram a partir da tecnificação do campo. Os objetivos específicos apresentar os principais fatores que levaram a transformação do complexo rural em Complexo Agroindustrial, apresentar como as inovações tecnológicas que ocorreram no campo a partir da Revolução Verde; Como as políticas desenvolvimentistas apoiam estas transformações e observar a influência de diferentes complexos agroindustriais no valor agropecuário municipal e elucidar seus efeitos sobre a geração de empregos e sobre a renda per capita. 
Como base para o referencial teórico, foram feitas pesquisas bibliográficas em livros de autores como Angela Kageyama (1987), Geraldo Muller (1989), Graziano da Silva (1996) e Karl Kautsky (1980), pesquisas em artigos, revistas, dissertações e teses para compreensão da formação e desenvolvimento dos Complexos Agroindustriais no Brasil como um todo.

O livro está estruturado em quatro capítulos. O primeiro capítulo aborda o conceito dos Complexos Agroindustriais (CAls) e seus desdobramentos, a transformação do complexo rural em agroindustrial, as inovações tecnológicas, a modernização da agricultura bem como a relação do Complexo Agroindustrial com o desenvolvimento econômico. No segundo capítulo temos uma abordagem dos programas desenvolvimentistas em Goiás, os Complexos Agroindustriais que se desenvolveram no Estado e as principais atividades agropecuárias destes. O terceiro capítulo diz respeito a metodologia utilizada para a realização deste trabalho e o quarto capítulo traz uma análise da influência dos complexos agroindustriais em Rio Verde e Quirinópolis, bem como seus impactos econômico-sociais, e por fim são feitas as considerações do que foi apresentado no corpo deste trabalho.

\section{COMPLEXOS AGROINDUSTRIAIS}

Este capítulo aborda a teoria dos Complexos Agroindustriais (CAls), desde a sua concepção, desdobramentos, bem como a transformação do Complexo Rural em agroindustrial, as inovações tecnológicas e suas interligações com o desenvolvimento econômico. Nesse sentido, o objetivo desta primeira etapa do trabalho consiste em analisar as transformações que ocorreram nas últimas décadas, dada a modernização no campo, baseado no maior controle e conhecimento da natureza, permitindo a união da agricultura com a indústria que reflete a possibilidade de reproduzir artificialmente as condições naturais da produção agrícola.

\subsection{CONCEITOS E DESDOBRAMENTOS}

O conceito de complexo é utilizado para representar e/ou designar vários elementos, sendo considerado como "um grupo ou conjunto de coisas que tem qualquer ligação ou nexo entre si" (HOLANDA, 1986, p. 440). Podemos então utilizar o conceito de complexo como um conjunto de elementos que pertencem a uma cadeia de fatores coordenados e relacionados entre si e que compõem as várias etapas de um processo.

A base para o entendimento de Complexo Agroindustrial (CAI) surge nos Estados Unidos na década de 50 com os professores John Davis \& Ray Goldberg, da Universidade de Harvard, juntamente com o conceito de Agribusiness. De acordo com Araújo, Wedekin e Pinazza: 
Pela definição de Goldberg e Davis, o "agribusiness" é "a soma total das operações de produção e distribuição de suprimentos agrícolas; as operações de produção nas unidades agrícolas; e o armazenamento, processamento dos produtos agrícolas e itens produzidos com eles". Dessa forma, o "agribusiness" engloba os fornecedores de bens e serviços à agricultura, os produtores agrícolas, os processadores, transformadores e distribuidores envolvidos na geração e no fluxo dos produtos agrícolas até o consumidor final. Participam também nesse complexo os agentes que afetam e coordenam o fluxo dos produtos, tais como o governo, os mercados, as entidades comerciais, financeiras e de serviços. (ARAÚJO; WEDEKIN; PINAZZA, 1990, p.3)

Segundo Muller, pode se entender por Complexo Agroindustrial como o:

O conjunto de relações entre indústria e agricultura na fase em que esta mantém intensas conexões para trás, com a indústria para a agricultura e para frente, com as agroindústrias e outras unidades de intermediação que exercem impactos na dinâmica agrária. O Complexo Agroindustrial é uma forma de unificação das relações entre os grandes departamentos econômicos com os ciclos e as esferas de produção, distribuição e consumo, relações estas associadas às atividades agrárias. (MÜLLER, 1989a, p.41).

O Complexo Agroindustrial é subdividido em dois agregados: o primeiro é a parte que antecede a produção rural, chamado de montante do Complexo Agroindustrial, no qual se tem todo o conjunto de setores que participam da produção dos insumos agrícolas consumidos pelos produtores, como máquinas e equipamentos, fertilizantes, adubos, sementes, combustível. Já o segundo agregado, é a parte que recebe a produção dos produtores, chamada de jusante do complexo agroindustrial, que armazena, comercializa, processa e distribui o produto no mercado como as commodities em geral (STREETER, 1991).

A noção de Complexo Agroindustrial serve então para caracterizar as relações intersetoriais indústriaagricultura-comércio-serviços num padrão agrário moderno, de modo que o setor agropecuário passa a ser visto de maneira integrada e dependente da indústria, tanto a montante, quanto a jusante do processo.

\subsection{AS TRANSFORMAÇÕES DO COMPLEXO RURAL EM AGROINDUSTRIAL}

Os Complexos Agroindustriais nascem a partir do processo de desenvolvimento interno do mercado no capitalismo. Segundo Graziano da Silva (1996), tais complexos surgem a partir de dois processos:

Um de destruição da economia natural, pela retirada progressiva dos vários componentes que asseguravam a "harmonia" da produção assentada na relação Homem-Natureza (e suas contradições); e o outro, de uma nova síntese, de recomposição de uma outra "harmonia" - também permeada por novas contradições - baseada no conhecimento e controle cada vez maior da Natureza e na possibilidade da reprodução artificial das condições naturais da produção 
agrícola. A esta passagem se denomina industrialização da agricultura. (GRAZIANO DA SILVA, 1996, p.3).

A relação do homem com o campo era apenas uma relação de trabalho e terra, eles realizavam seus plantios e colhiam seus frutos com a utilização apenas de ferramentas rústicas e força braçal, ou seja, de forma natural. A reprodução de forma artificial, com a industrialização da agricultura, redefine toda a relação do homem com a terra, que passa a depender do capital.

O alemão Kautsky (1980), um dos precursores do estudo do início da união da agricultura com a indústria, no final do século passado, em seu livro $A$ Questão Agrária, explica o surgimento da industrialização no campo da seguinte maneira:

O camponês deixa de ser, pois, o senhor na sua exploração agrícola. Esta se torna um apêndice da exploração industrial por cujas conveniências deve orientar-se (.) Frequentemente, também cai sob a dependência técnica da exploração industrial (...) Como nos demais setores da sociedade capitalista, a indústria acaba por vencer a agricultura (...). A indústria constitui a mola não apenas de sua evolução mas ainda da evolução agrícola. Vimos que foi a manufatura urbana que dissociou, no campo, a indústria e a agricultura, que fez do rural um lavrador puro, um produtor dependente dos caprichos do mercado, que criou a possibilidade de sua proletarização (...) Foram criadas assim as condições técnicas e científicas da agricultura racional e moderna, a qual surgiu com o emprego de máquinas e deu-lhe, pois, superioridade da grande exploração capitalista sobre a pequena exploração camponesa. (KAUTSKY, 1980, p. 281-318).

A citação acima nos mostra o início do processo de apropriação do capital na agricultura, no século passado. Kautsky (1980) elucida em sua obra o início da interdependência que passa a existir entre a indústria e agricultura, dando origem então ao processo de constituição dos Complexos Agroindustriais, que no Brasil se estabelece na década de 1970.

No Brasil, os autores Kageyama (1987) e Graziano da Silva (1996) consideram a existência de um "Complexo Rural", anteriormente à constituição dos chamados Complexos Agroindustriais. Nesta situação haveria uma dinâmica muito simples na qual a atividade agropecuária, ou o setor rural, mantinha poucas ou quase nenhuma relação com atividades externas às fazendas, a não ser com o mercado externo para um único produto, de modo geral, em todo o circuito produtivo com valor comercial, como é o caso da lavoura cafeeira desde o século XIX. Este Complexo Rural atinge seu auge em 1850, entrando num processo de crise e desarticulação. No seio do mesmo é gerado o chamado Complexo Cafeeiro que tem seu período de auge por volta dos anos de 1930, estendendo-se até a década de 1960. 
Segundo Araújo, Wedekin e Pinazza (1990), por um lado, a propriedade agrícola transformou sua atividade de subsistência em uma operação de mercado, em que os agricultores consomem, cada vez menos, o que produzem. Ou seja, o moderno agricultor tornou-se um especialista, confinado às operações de cultivo e criação. Por outro lado, as funções de armazenar, processar e distribuir alimento e fibra vai se transferindo paulatinamente, em larga escala, para organizações além da fazenda. No setor a jusante da fazenda, pode-se observar a formação de complexas estruturas de armazenagem, transporte, processamento, industrialização e distribuição que passam a integrar tal complexo antes do produto final chegar à mesa do consumidor. A agricultura passa ser um apêndice da indústria, pois se torna um setor dependente da mesma, já que perde sua autonomia de produção, armazenagem, comercialização e distribuição. Segundo Szmrecsányi (1983, p. 144) “o setor deixa de constituir um compartimento semiautônomo e fechado, para tornar-se um sistema aberto e integrado aos setores que Ihes são complementares no contexto da encomia como um todo". Temos então a formação de uma relação em cadeia, que se torna complexa e direcionada sempre a ganhos maiores, com uma maior produtividade que se estabelece com a inserção da indústria.

Além disso, instituições públicas do Estado e privadas, como bancos, possuem uma ligação e apoio indiretos que contribuem para a viabilização e realização das atividades como um todo nestes Complexos Agroindustriais. O governo atua com políticas públicas de incentivo e os bancos com o financiamento e crédito para o setor. A Figura 1 nos apresenta todo o esquema desse nível de integração dos setores que formam o Complexo Agroindustrial sugerido por Szmecsányi (1983):

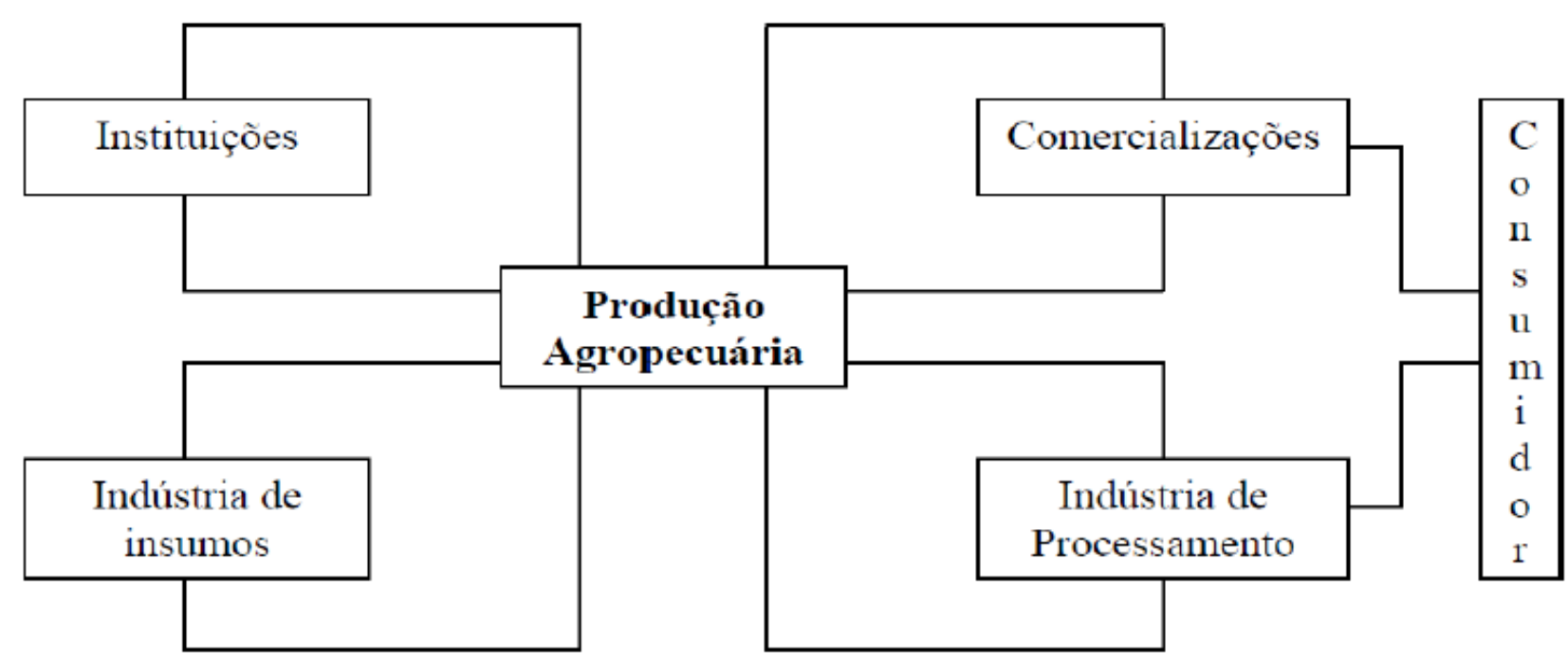

Figura 1: Esquema do Complexo Agroindustrial.

Fonte: Szmrecsányi (1983). 
Como podemos observar na Figura 1, há um processo de integração de vários setores que passam a vigorar dentro do complexo agroindustrial desde o papel das instituições, a indústria dos insumos, da indústria de processamento e de comercialização até finalmente o consumidor final. As instituições envolvem os vários serviços prestados ao setor agropecuário (crédito, assistência técnica, extensão, pesquisa, etc.). A indústria de insumos abrange os ramos industriais e comerciais que se orientam para o atendimento das necessidades produtivas agropecuárias (corretivos, fertilizantes, defensivos, equipamentos etc.). Já a comercialização diz respeito aos serviços de estocagem e negociação dos produtos agropecuários (cooperativas, redes de distribuição etc.). E por último, de acordo com Szmecsányi (1983), temos a indústria de processamento, que inclui os ramos industriais com produção predominantemente baseada em matérias-primas de origem agropecuária. Portanto, este nível de integração dos diversos segmentos revela a importância de cada elo neste complexo, evidenciando o papel fundamental de cada um na efetividade da produção até o mercado final.

Graziano da Silva (1996) ressalta que o momento em que a indústria passa a consumir, processar e transformar a produção agrícola, torna-se simultaneamente o momento em que o produtor se torna inteiramente dependente dessa indústria ascendente à jusante do processo:

A industrialização do campo é um momento específico do processo de
modernização, a reunificação agricultura-indústria num patamar mais elevado
que do simples consumo de bens industriais pela agricultura. É o momento da
modernização a partir do qual a indústria passa a comandar a direção, as formas
e o ritmo da mudança na base técnica agrícola, o que ela só pode fazer após a
implantação do D1 para a agricultura no país. (GRAZIANO DA SILVA, 1996, p.32). Esta transformação no mundo agrícola traz à tona uma dependência do produtor rural tanto à montante, quanto à jusante do processo. A terra que antes era usada apenas como um meio de subsistência, onde o produtor dependia apenas de seus esforços com o cultivo para obter seu alimento, passa a ser utilizada como parte de um grande complexo, em que este produtor se torna dependente da indústria e de tecnologias para o cultivo, como máquinas e equipamentos, adubos, fertilizantes e defensivos químicos antes mesmo da plantação (a montante) e escoa este produto também para a indústria (a jusante), que é responsável pelo processamento desta produção no campo.

\subsection{AS INOVAÇÕES TECNOLÓGICAS E A MODERNIZAÇÃO DA AGRICULTURA}

De acordo com Delgado (1985), as transformações técnicas que ocorreram no campo é um processo distinto da formação dos Complexos Agroindustriais, que se dá na evolução dos meios de produção 
usados na agricultura, tendo como resultado os bens de produção industrial em substituição aos "produtos naturais" no campo.

Graziano da Silva (1996) afirma que

O processo de modernização, ao mesmo tempo que implica a mercantilização intra- setorial da agricultura, promove a substituição de elementos internos do complexo rural por compras extra-setoriais (máquinas e insumos), abrindo espaço para a criação de bens de capital e insumos para a agricultura [...]. (GRAZIANO DA SILVA, 1996, p. 20).

É importante observar que as transformações estruturais ocorrem na transição do Complexo Rural para o agroindustrial, principalmente por meio das mudanças de ordem tecnológica, pela substituição dos elementos internos por externos, introduzindo um processo de mecanização e do uso de insumos agrícolas modernos sem precedentes.

Para Graziano da Silva (1996), os principais avanços em inovação tecnológica pertencem à indústria a montante da agricultura pode se subdividir em três linhas: as inovações mecânicas, físico-químicas e biológicas. A inovação mecânica está ligada a produção de tratores, máquinas, colhedeiras, equipamentos de irrigação, beneficiamento, entre outros. A inovação físico-química está relacionada à indústria de fertilizantes e defensivos para controle de pragas, como inseticidas, fungicidas, herbicidas. Por último a inovação biológica, que traz melhorias genéticas tanto na agricultura como na pecuária, novos cultivares geneticamente modificados que também visam o maior controle de pragas. Guimarães (1989) ressalta que esta Revolução Agrícola acontece no Brasil, ao mesmo tempo, que se inicia a chamada Revolução Verde1, que traz como princípios técnicos o uso intensivo destas três inovações técnicas, com o objetivo de ganhos de produtividade.

Tais transformações na base técnica são fortemente subsidiadas pela ação estatal no intuito de integrar a indústria com a agricultura, ofertando subsídios de crédito, incentivos fiscais e de exportação. No Brasil esta transformação é consolidada pelo Sistema Nacional de Crédito Rural (SNCR) que por meio de fundos de financiamento viabiliza a agroindustrialização pelo capital financeiro.

Entretanto, praticamente todas as tais transformações na base técnica são fortemente subsidiadas pela ação estatal no intuito de integrar a indústria com a agricultura, ofertando subsídios de crédito, incentivos fiscais e de exportação. A partir de 1965, no Brasil esta transformação é consolidada pela criação do Sistema Nacional de Crédito Rural (SNCR) que por meio de fundos de financiamento viabiliza a agroindustrialização pelo capital financeiro (DELGADO, 1985). 


\section{Os Complexos Agroindustriais Nos Municípios De Rio Verde E Quirinópolis-Go}

Graziano da Silva (1996) esquematiza o processo de modernização da agricultura (Figura 2). A partir dos anos 50 até os anos 80, o chamado Novo Padrão Agrícola nada mais é que a constituição dos Complexos Agroindustriais por meio do surgimento do D1 (industrialização geral da economia) que posteriormente é implementada na agricultura financiada principalmente por recursos oriundos dos bancos estatais:

\section{MODERNIZAÇÄO DA AGRICULTURA}

Anes 50: elaraça do do uso de insumos mademas (basicamante importaçónes)

55.65. implantaçăo do D1 geral da economis (industrializaçắ

perada)

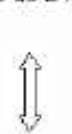

EES5 internalizaçăo do D1 para a agricultura

Industrializaçăa

da ulura

25805 integlação de capitais
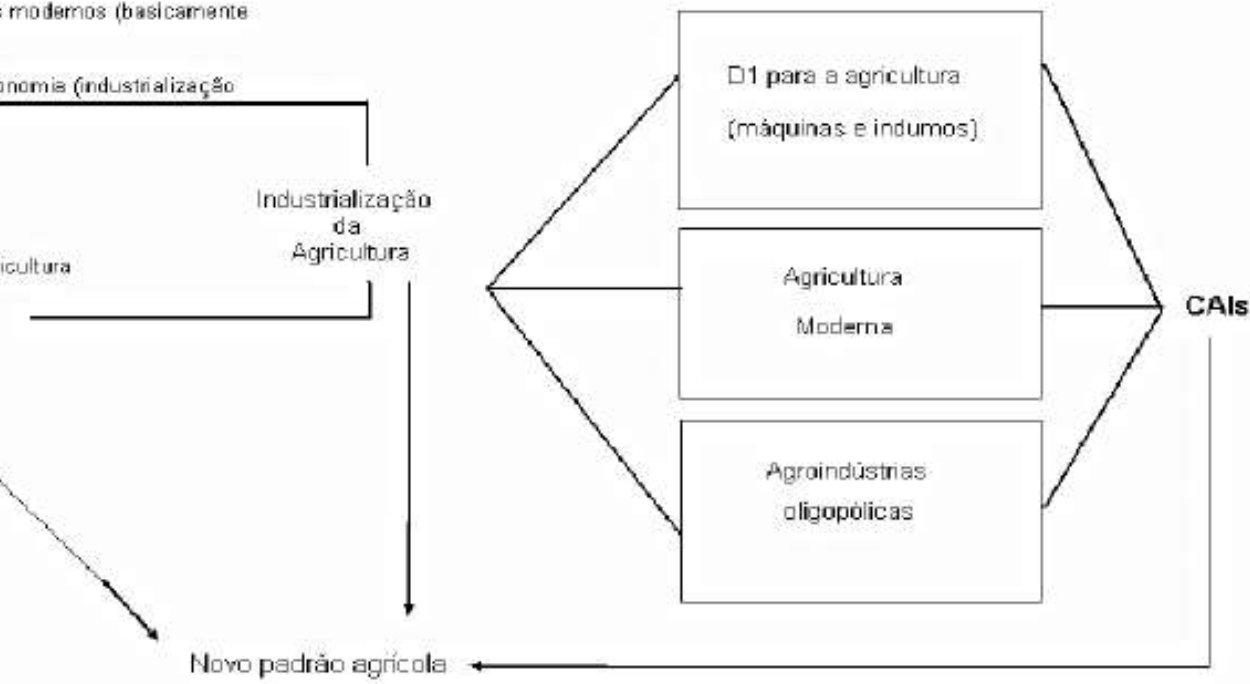

Nowo padrào agricola

Figura 2: Processo de Modernização da Agricultura.

Fonte: Graziano da Silva (1996).

Este novo padrão agrícola, que passa a utilizar de máquinas e insumos para a produção, pode ser observado no Brasil com a grande evolução da utilização de tratores, fertilizantes e defensivos (Tabela 1), nos anos compreendidos entre 1967 e 1975: 
Tabela 1: Brasil: índices simples da utilização de insumos básicos pela agricultura (1967 - 1975).

\begin{tabular}{c|c|c|c}
\hline Ano & Tratores (n $^{\mathbf{}}$.) & Fertilizantes (ton.) & Defensivos (ton.) \\
\hline 1967 & 110 & 159 & 126 \\
\hline 1968 & 121 & 214 & 178 \\
\hline 1969 & 132 & 225 & 201 \\
\hline 1970 & 146 & 356 & 195 \\
\hline 1971 & 158 & 415 & 217 \\
\hline 1972 & 181 & 622 & 314 \\
\hline 1973 & 211 & 598 & 417 \\
\hline 1974 & 246 & 704 & 500 \\
\hline 1975 & 287 & 648 & 374 \\
\hline
\end{tabular}

Fonte: Graziano da Silva (1981).

Tais inovações tecnológicas e seu expressivo crescimento de utilização no campo contribuíram de forma significativa para a elevação da produtividade da terra. Nesta fase, se concretiza então a maior dependência da agricultura em relação ao setor industrial com a internalização do D1 na agricultura, e dependência do setor financeiro, exigindo do Estado planos e programas específicos para o setor, com o intuito de fomentar este novo modelo de processo produtivo, denominado Complexo Agroindustrial.

\subsection{O COMPLEXO AGROINDUSTRIAL E O DESENVOLVIMENTO ECONÔMICO}

O Complexo Agroindustrial pode desempenhar papel fundamental no processo de desenvolvimento econômico de uma nação, ao possibilitar uma maior dinâmica tanto na indústria, como no comércio e serviços, gerando efeitos de encadeamento no resto da economia. Vários países passaram por um processo de transformação econômica, ao considerar as mudanças ocorridas na agricultura. Segundo Johnston e Mellor (1961), a agricultura teve papel fundamental no processo de urbanização e de industrialização, atuando em cinco funções básicas:

a) Liberação de mão-de-obra para ser empregada em outros setores da economia:

No Brasil, com o início do processo de industrialização, a agricultura além de fornecer os alimentos e matérias-primas que o setor urbano precisa, fornece também mão-de-obra. A medida que a produtividade no campo aumenta, é gerado em consequência um excedente de trabalhadores empregados na agricultura. De acordo com Lucena e Souza (1999), este excedente de trabalhadores 
migra para a cidade, ocupando novos postos de trabalho sem reduzir a oferta de alimentos e matériasprimas.

b) Fornecimento de alimentos e matérias-primas para o setor urbano-industrial:

O fornecimento de alimentos e matérias-primas para o setor urbano-industrial é vital no processo de desenvolvimento e de acordo com Castro (1979), só é possível este fornecimento quando a população rural com seu trabalho produz mais do que consome no campo, sendo responsável então pelo surgimento e crescimento da vida na cidade.

c) Geração de ganhos cambiais, por meio da exportação de produtos agrícolas:

A geração de divisas com a exportação de produtos agrícolas é fundamental para o crescimento do produto nacional, financiar importações, amortizar a dívida externa, viabilizando então a importação de máquinas e equipamentos necessários ao processo de industrialização.

d) Geração de capital, objetivando principalmente a expansão do setor não-agrícola:

A transferência de poupança para a expansão industrial é também uma das funções da agricultura no processo de desenvolvimento. De acordo com Souza (1999, p. 286) "Essa transferência pode ser espontânea ou compulsória, por meio do mecanismo de preços, do confisco cambial de exportações agrícolas e da tributação". Os agricultores e membros de elites agrárias podem aplicar seus rendimentos e lucros na economia urbana, de maneira espontânea, e de maneira compulsória parte do excedente pode ser extraído e utilizado como forma de investimento em outros setores da economia.

e) Construir mercados para bens industriais, complementando os mercados urbanos:

Com os complexos agroindustriais, a agricultura constitui mercado ao depender e adquirir os insumos industriais (os corretivos, fertilizantes, defensivos, implementos, equipamentos), que colaboram para geração de novos empregos, tanto na indústria como no comércio e contribuem decisivamente para o dinamismo da economia nacional. Gremaud, Vasconcellos e Toneto Junior (2002) nos dizem que a agricultura gerou matéria prima, mão- de-obra, divisas e alimentos para a indústria, e foi essencial para o desenvolvimento desta.

\section{PANORAMA DOS COMPLEXOS AGROINDUSTRIAIS EM GOIÁS}

Neste capítulo serão abordados os programas desenvolvimentistas de âmbito federal e estadual que contribuíram para o surgimento e crescimento dos Complexos Agroindustriais em Goiás, o importante 
papel a Empresa Brasileira de Pesquisa Agropecuária (EMBRAPA) neste processo, a evolução da utilização de máquinas, fertilizantes e defensivos que elevam a produtividade no campo e possibilita o crescimento populacional urbano, crescimento industrial e consequentemente de elevação do número de empregos no setor, bem como as principais atividades agrícolas destes complexos.

\subsection{OS PROGRAMAS DESENVOLVIMENTISTAS EM GOIÁS}

Os programas desenvolvimentistas federais que influenciaram o desenvolvimento de Goiás, foram criados com o objetivo de reduzir as desigualdades regionais entre os estados da federação. No começo da década de 1970 com a inserção do II Plano Nacional de Desenvolvimento (II PND), se inicia então a desconcentração industrial de São Paulo. O II PND tinha como objetivo dar continuidade as elevadas taxas de crescimento econômico contempladas no período do Milagre Econômico (1968 a 1973). Tal programa abrangeu o processo de desconcentração industrial, ponto chave para seguir com crescimento econômico. Ademais, o plano favoreceu os projetos de infraestrutura, como é o caso das rodovias, ampliou de forma significativa a expansão da malha rodoviária brasileira, com elevação de 85\% no período de 1960 a 1980, através do Plano de Integração Nacional (PIN). Com a expansão da infraestrutura no país, o II PND contribuiu para a criação de novos polos de crescimento, principalmente em Goiás, que passa a fazer parte das regiões dinâmicas de crescimento industrial e agropecuário, antes concentradas apenas na região Sudeste do país.

Em 1961, no governo de Mauro Borges, a criação do Plano de Desenvolvimento em Goiás (PDEG) sinaliza que este plano seria bastante inovador na medida em que cria se uma estrutura técnica com o objetivo de materializar a industrialização do estado com estratégias de promoção da expansão industrial que são apoiadas com a criação da Secretaria de Indústria e Comércio (SIC) e a abertura de crédito industrial no Banco do Estado de Goiás (BEG). (ARRAIS, 2007).

O PDEG dividiu o estado de Goiás em seis regiões distintas: Norte, Planalto, Mato Grosso de Goiás, Goiânia, Estrada de Ferro e Sudoeste. As regiões de Goiânia e Mato

Grosso de Goiás foram definidas como polos de crescimento. Os investimentos em capital social concentraram em Goiânia, enquanto que os investimentos no setor agrícola, concentrados em Mato Grosso de Goiás. Na Figura 3 podemos observar esta divisão regional no Governo Mauro Borges de 1961 a 1965, destacando os principais municípios do estado: 


\section{Os Complexos Agroindustriais Nos Municípios De Rio Verde E Quirinópolis-Go}

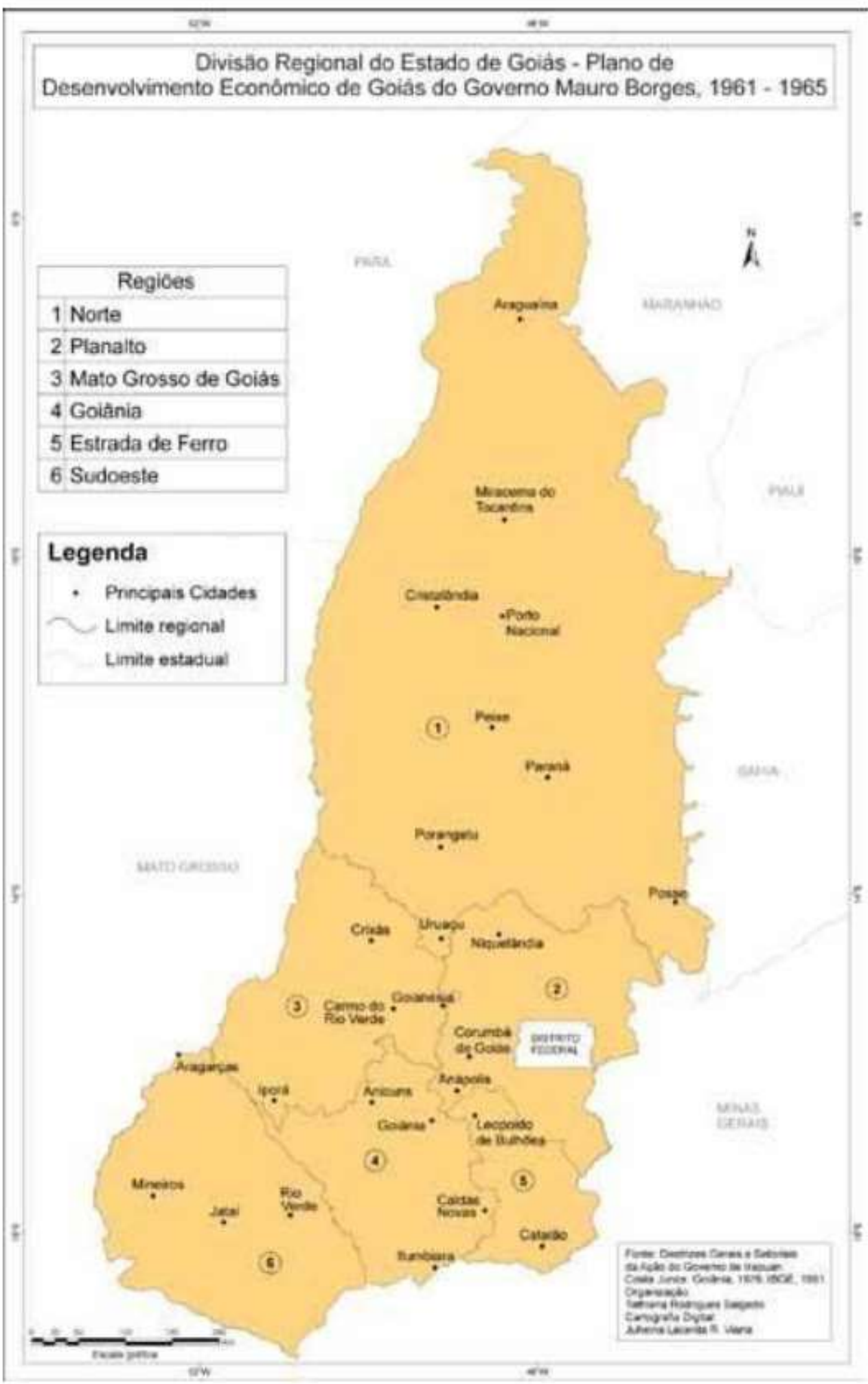

Figura 3: Divisão regional do Estado de Goiás - Plano de Desenvolvimento Econômico de Goiás (1961

$-1965)$.

Fonte: Salgado (2012). 
Além do PDEG, houve também a criação do Programa de Desenvolvimento do Centro- Oeste (PRODOESTE) que teve papel importante no financiamento das ações do governo para a expansão da malha rodoviária na região Sul de Goiás e Distrito Federal, e também na construção de armazéns, frigoríficos e silos.

Por meio das políticas do II PND foi possível a implementação de importantes programas regionais de desenvolvimento em Goiás, destaque para o Programa de Desenvolvimento dos Cerrados (POLOCENTRO), bem como o Programa de Cooperação nipo- brasileira para o desenvolvimento dos cerrados (PROCEDER II), que passaria a contribuir significativamente para a tecnificação da agropecuária no centro do país, elevando a produtividade da agricultura, ao mesmo tempo em que promoveria a atração de novos investimentos por meio dos grandes conglomerados agroindustriais (ARRIEL, 2017).

Assim, o conjunto de políticas públicas implementadas, deram um relevante suporte para a implantação de técnicas de produção mais avançadas no setor agrícola em Goiás. Na década de 1970, foram promovidas pelo Governo Federal, ações que resultaram em mudanças na estrutura agropecuária brasileira, destaque para os elevados investimentos em pesquisas científicas, tendo como protagonista a Empresa Brasileira de Pesquisa Agropecuária (EMBRAPA) recém-criada (ARRIEL, 2017).

O papel da Embrapa foi fundamental para a expansão da área agrícola nos cerrados, a empresa passou a o coordenar as pesquisas de melhoramentos das sementes, correção dos solos, eliminação de doenças e adequação de produtos ao mercado, o que elevou a produtividade no campo, promovendo a modernização dos meios de produção. Especificamente no Cerrado, a criação da Embrapa foi fundamental para a elevação desta produtividade agrícola, resultado eficiente da correção de solos ácidos, na medida em que se viabilizou o desenvolvimento de novas variedades agrícolas adaptadas ao Cerrado (ARRIEL, 2017).

Na década de 60, o governo investiu também em políticas de crédito, com o Sistema Nacional de Crédito Rural (SNCR) e também com as Políticas de Garantias de Preços Mínimos (PGPM), que garantiram ao produtor rural um preço mínimo de seus produtos no momento da comercialização da safra. Dessa forma, o governo além de eliminar incertezas futuras, garantiria uma renda mínima ao produtor (GREMAUD, VASCONCELLOS e TONETO JÚNIOR, 2002).

Este conjunto de políticas e programas contribuiu significativamente para a tecnificação da agropecuária em Goiás, bem como na região Centro-Oeste, elevando a produtividade no campo e 
dando maior atratividade de grandes conglomerados agroindustriais para o Estado, fortalecendo o setor e o colocando no centro da dinâmica econômica goiana.

\subsection{O COMPLEXO AGROINDUSTRIAL EM GOIÁS}

A mudança nas práticas agropecuárias de produção com o forte apoio de políticas públicas torna então a agropecuária dependente e integrada à atividade industrial que em Goiás se inicia no decorrer da década de 1970 e tem seus principais reflexos na década de 1980, com a atração de plantas industriais, principalmente alimentícias (ARRIEL, 2017).

De acordo com a Figura 4, entre 1975 e 2006 em Goiás houve forte evolução da demanda por bens produzidos pela indústria à montante do processo produtivo (tratores, fertilizantes e defensivos). $\mathrm{O}$ número de estabelecimentos que utilizam tratores cresce $242 \%$, o uso de fertilizantes tem o crescimento de $213 \%$ e a quantidade de estabelecimentos que utilizam defensivos químicos tem um crescimento de $27 \%$ de 1975 para 1985, porém nos anos seguintes sua utilização diminui no estado:

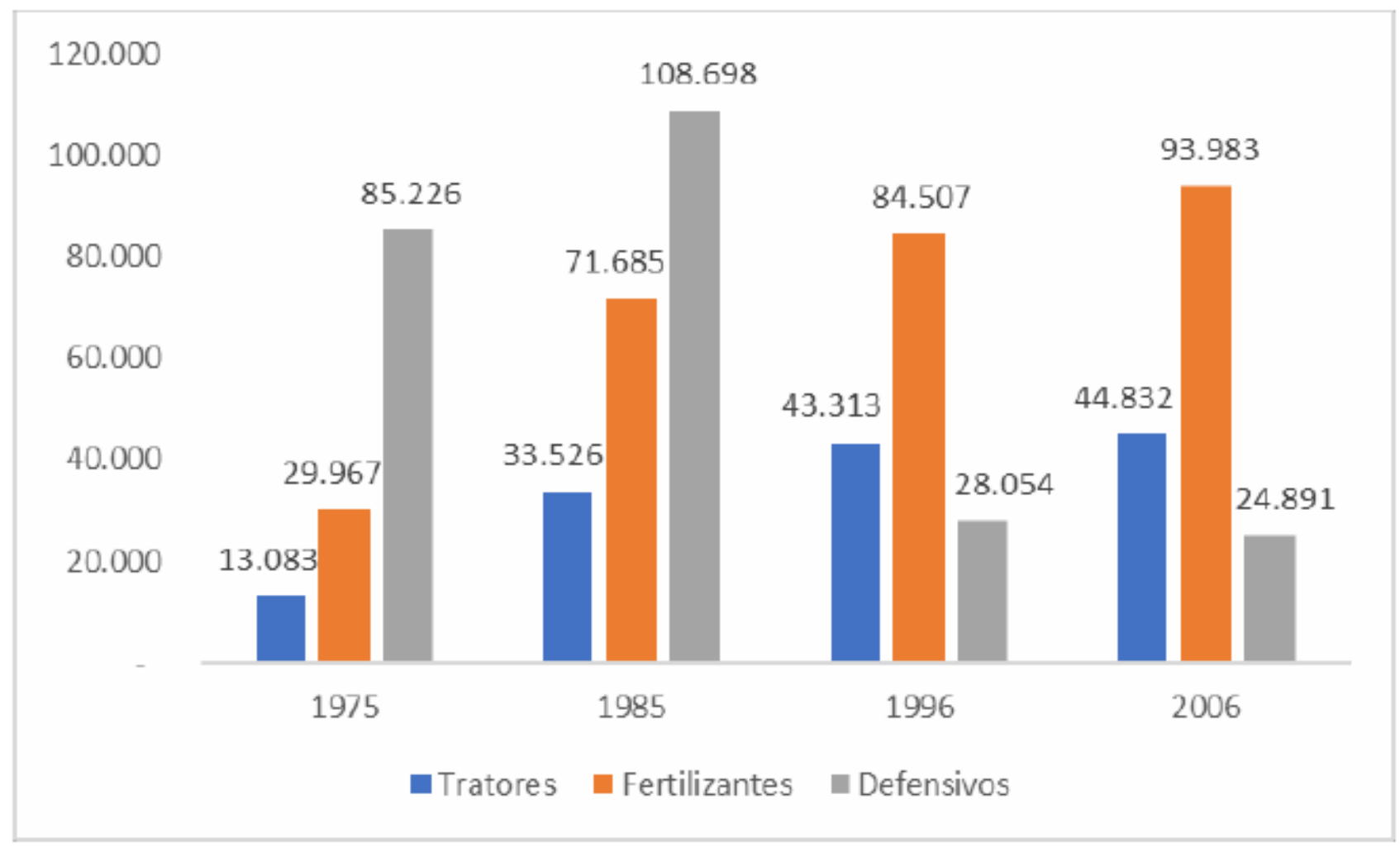

Figura 4: Estado de Goiás - número de estabelecimentos agrícolas com tratores, fertilizantes e defensivos agrícolas (1975-2006).

Fonte: IBGE - Censos agropecuários de 1975 a 2006. Elaboração própria. 
A intensificação do uso de máquinas, fertilizantes e defensivos agrícolas passa a fomentar a indústria a montante, na medida em que se consolida a transição da agricultura de baixa produtividade para a formação dos Complexos Agroindustriais, com um aumento significativo da produtividade no campo, em concomitância com o processo de êxodo rural, o que potencializa o deslocamento da população goiana para os centros urbanos, liberando então mão-de-obra para ser empregada em outros setores da economia, conforme destacado por Johnston \& Mellhor (1961) como uma função básica para o processo de transformação econômica. A Figura 5 revela esse processo de crescimento populacional urbano no estado de Goiás. Tal população urbana, que em 1950 representava apenas 20\% do total de habitantes em Goiás, em 2010 passou a representar mais de 90\% da população total goiana:

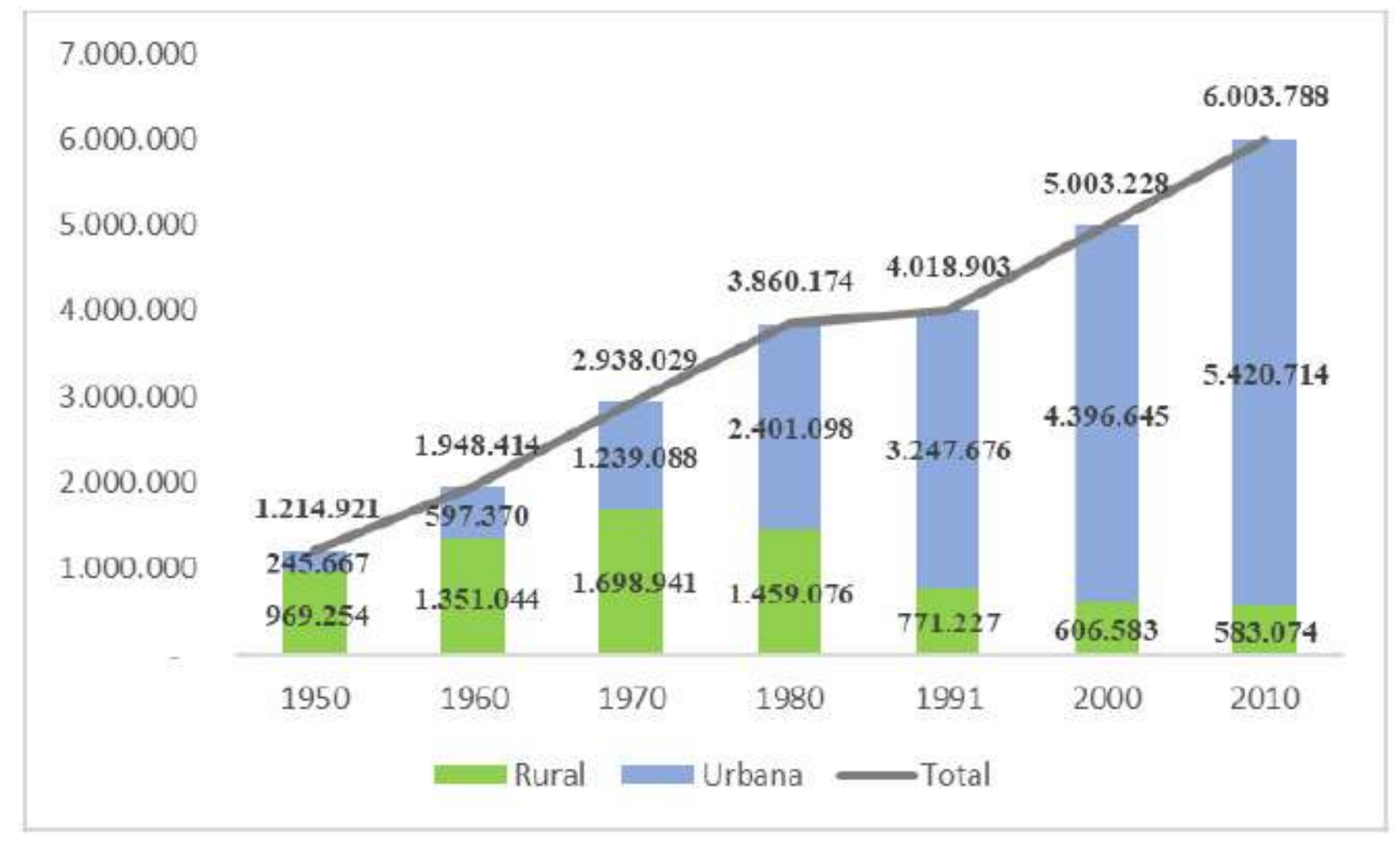

Figura 5: Estado de Goiás - Evolução da população urbana, rural e total (1950 - 2010).

Fonte: IBGE (2010). Elaboração própria.

Os Complexos Agroindustriais em Goiás que se desenvolvem para suprir o crescimento da população no meio urbano são potencializados com a migração da capital nacional, Brasília, para o estado em 1960, a chegada da ferrovia em Anápolis, e também com a construção da nova capital de Goiás, Goiânia. Segundo Arriel (2017), boa parte deste crescimento industrial se concentra inicialmente em Goiânia e Anápolis devido à concentração populacional que ocorre nas duas cidades, porém, à medida 
que os custos produtivos se elevam, como o da mão de obra, outros municípios no estado passam a fazer parte da rota de industrialização: Catalão, Itumbiara, Jataí e Rio Verde.

De acordo com a Tabela 2, podemos observar que Goiânia apesar de manter em alta a sua produção industrial, perde participação em relação aos demais municípios do Estado. Os municípios de Rio Verde e Catalão mostram um significante crescimento no período analisado, elucidando esta desconcentração industrial em Goiás.

Tabela 2: Os dez maiores municípios da indústria goiana, segundo participação nas vendas industriais - anos selecionados.

\begin{tabular}{|c|c|c|c|c|c|c|c|}
\hline \multicolumn{2}{|c|}{1998} & \multicolumn{2}{|c|}{2005} & \multicolumn{2}{|c|}{2010} & \multicolumn{2}{|c|}{2014} \\
\hline Município & $\begin{array}{c}\% \\
\text { estadual }\end{array}$ & Município & $\begin{array}{c}\% \\
\text { estadual }\end{array}$ & Município & $\begin{array}{c}\% \\
\text { estadual }\end{array}$ & Município & $\begin{array}{c}\% \\
\text { estadual }\end{array}$ \\
\hline Goiânia & 26,17 & Goiânia & 14,22 & Anápolis & 22,21 & Anápolis & 15,55 \\
\hline Anápolis & 9,44 & Catalão & 10,79 & Catalão & 11,61 & Rio Verde & 9,38 \\
\hline Luziânia & 8,35 & Rio Verde & 10,08 & Goiânia & 9,39 & Goiânia & 9,21 \\
\hline Itumbiara & 6,03 & Anápolis & 9,59 & Rio Verde & 8,03 & Catalão & 9 \\
\hline Rio Verde & 3,63 & Luziânia & 5,89 & $\begin{array}{l}\text { Aparecida } \\
\text { de Goiânia }\end{array}$ & 4,1 & Itumbiara & 4,79 \\
\hline Trindade & 3,48 & Itumbiara & 5,26 & $\begin{array}{c}\text { Alto } \\
\text { Horizonte }\end{array}$ & 3,69 & $\begin{array}{l}\text { Aparecida } \\
\text { de Goiânia }\end{array}$ & 4,72 \\
\hline $\begin{array}{l}\text { Aparecida } \\
\text { de Goiânia }\end{array}$ & 3,4 & $\begin{array}{l}\text { Aparecida } \\
\text { de Goiânia }\end{array}$ & 4,01 & Luziânia & 3,51 & Jataí & 3,35 \\
\hline Catalão & 2,8 & Jataí & 3,45 & Itumbiara & 3,51 & Luziânia & 2,42 \\
\hline São Simão & 2,24 & Goiatuba & 3,06 & Jataí & 3,03 & $\begin{array}{l}\text { Senador } \\
\text { Canedo }\end{array}$ & 2,12 \\
\hline Jataí & 2,02 & Niquelândia & 2,46 & Trindade & 1,61 & $\begin{array}{c}\text { Bela Vista } \\
\text { de Goiás }\end{array}$ & 1,8 \\
\hline Subtotal & 67,55 & & 68,81 & & 70,7 & & 62,33 \\
\hline Outros & 32,45 & & 31,19 & & 29,3 & & 37,67 \\
\hline $\begin{array}{c}\text { Estado de } \\
\text { Goiás }\end{array}$ & 100 & & 100 & & 100 & & 100 \\
\hline
\end{tabular}

Fonte: IBGE (2014). Elaboração: Arriel (2017).

Segundo Pereira e Almeida Filho (2003), o desenvolvimento da agroindústria da soja, que é o principal grão cultivado em Goiás, se deu em três fases distintas: a primeira etapa foi à adaptação biológica da soja para o bioma do Cerrado na década de 1970, e consequentemente o início do beneficiamento do grão no Estado; a segunda etapa se dá com a expansão do cultivo do grão no Centro-Oeste, porém com uma infraestrutura debilitada; e a terceira etapa se desenrola quando há uma transferência de fábricas de beneficiamento de grãos para o Estado. 
Para fortalecer a representação de interesses dos produtores de grãos na microrregião do Sudoeste de Goiás, foi criada a COMIGO (Cooperativa Mista de Produtores do Sudoeste Goiano Ltda.) em 1975, tornando-se uma importante instituição que promoveria o desenvolvimento na região. O objetivo da cooperativa concentrava na construção de armazéns para depósito do grão colhido e realizar diretamente a comercialização destes. Borges (2012) relata que em 1978 já havia concluído a construção da primeira unidade de armazenamento em Rio Verde e sua primeira loja em Santa Helena de Goiás, e atuando em quatro ramos: armazenamento, assistência técnica, fornecimento de insumos e comercialização de grãos, contribuindo então para a germinação e desenvolvimento do

Complexo Agroindustrial da Soja em Goiás.

Posteriormente a consolidação da COMIGO, inicia-se uma nova fase de expansão da agroindústria no segmento de carnes em Goiás com a vinda da Perdigão para o estado a partir de 1998 para o município de Rio Verde, permitindo a formação do Complexo Agroindustrial da carne, com o abate e processamento de aves e suínos.

Na tabela 3 observamos que os empregos gerados pelo agronegócio em Goiás nos anos de 2014 e 2015 possuem uma participação de quase 16\% no total de empregos gerados no Estado, sendo que a principal parcela deste emprego agrícola é gerada a jusante do campo (57,1\% em 2015), e a menor parcela está a montante do processo (5,3\% em 2015):

Tabela 3: Estado de Goiás: Estoque e participação de empregos formais do agronegócio (2014 2015).

\begin{tabular}{l|c|c|c|c}
\hline \multirow{2}{*}{$\begin{array}{l}\text { Empregos formais por } \\
\text { segmento }\end{array}$} & \multicolumn{2}{|c|}{$\mathbf{2 0 1 4}$} & \multicolumn{2}{c}{$\mathbf{2 0 1 5}$} \\
\cline { 2 - 5 } & Empregos & Participação & Empregos & Participação \\
\hline $\begin{array}{l}\text { Total de empregos - segmento } \\
\text { antes da porteira / a montante }\end{array}$ & 12.779 & $5,3 \%$ & 12.715 & $5,3 \%$ \\
\hline $\begin{array}{l}\text { Total de empregos - segmento } \\
\text { dentro da porteira }\end{array}$ & 87.613 & $36,3 \%$ & 89.636 & $37,6 \%$ \\
\hline $\begin{array}{l}\text { Total de empregos - segmento } \\
\text { depois da porteira / a jusante }\end{array}$ & 141.044 & $58,4 \%$ & 136.110 & $57,1 \%$ \\
\hline Total de empregos agronegócio & $\mathbf{2 4 1 . 4 3 6}$ & $\mathbf{1 0 0 , 0} \%$ & $\mathbf{2 3 8 . 4 6 1}$ & $\mathbf{1 0 0 , 0} \%$ \\
\hline Total de empregos & $\mathbf{1 . 5 1 4 . 5 3 2}$ & $\mathbf{1 5 , 9 \%}$ & $\mathbf{1 . 5 0 1 . 3 9 7}$ & $\mathbf{1 5 , 9 \%}$ \\
\hline
\end{tabular}

Fonte: Ministério do Trabalho/ RAIS (2016). Elaboração: Instituto Mauro Borges (2017). 
Todos os resultados acima apresentados nos mostram que, a partir do uso da tecnologia antes inexistente no campo, de máquinas, equipamentos ou defensivos, revelam que a partir da Revolução Verde contribuem para o surgimento e desenvolvimento de Complexos Agroindustriais no estado de Goiás, constituindo mercado para bens industriais, conforme apresentado por Johnston \& Mellor (1961) e consequentemente gerando novos empregos, tanto a montante quanto a jusante do Complexo Agroindustrial.

\subsection{AS ATIVIDADES AGRÍCOLAS PRINCIPAIS}

As principais atividades agrícolas em Goiás se baseiam principalmente nas culturas de cereais (soja, milho e arroz) e cana-de-açúcar. A Figura 6 abaixo nos mostra a evolução destas culturas em termos de produção em toneladas desde a década de 70, até o ano de

2016.

O salto de produção da soja é de $10.243 \%$ no período analisado. De acordo com o IBGE (2016), em 1974, Goiás produziu 99 mil toneladas, sendo que em 2016 a produção foi de mais de 10 milhões de toneladas. O milho, no mesmo período saiu de pouco mais de 1 milhão para quase 6 milhões de toneladas, uma taxa de crescimento de $435 \%$. Na cultura da cana-de-açúcar temos o maior incremento de produção, que sai de 900 mil toneladas em 1974 para uma produção de 71 milhões em 2016, representando um crescimento de $7.796 \%$. A produção do arroz foi a única que sofre queda no período analisado, de 958 mil toneladas para 108 mil em 2016:

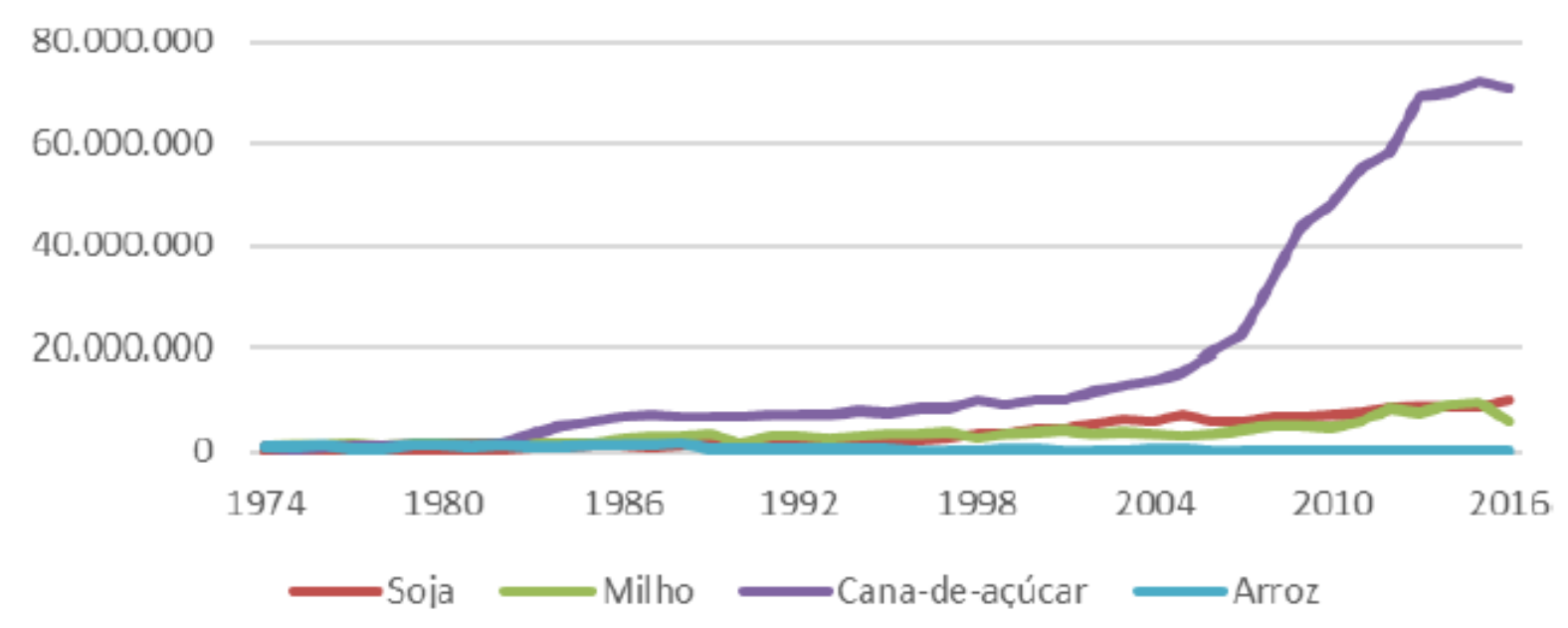

Figura 6: Estado de Goiás - Evolução da produção em toneladas (1974 - 2016).

Fonte: IBGE (2016). Elaboração própria. 
O agronegócio é um importante gerador de divisas para Goiás. De acordo com o Instituto Mauro Borges (IMB, 2017), quase 80\% das exportações do Estado em 2015 foram produtos do agronegócio. Esta alta representatividade nas exportações está concentrada principalmente no complexo da soja e carnes, que em 2015 constituíram respectivamente 39,01\% e 30,70\% do montante total de exportações nos principais setores do agronegócio, conforme Figura 7:
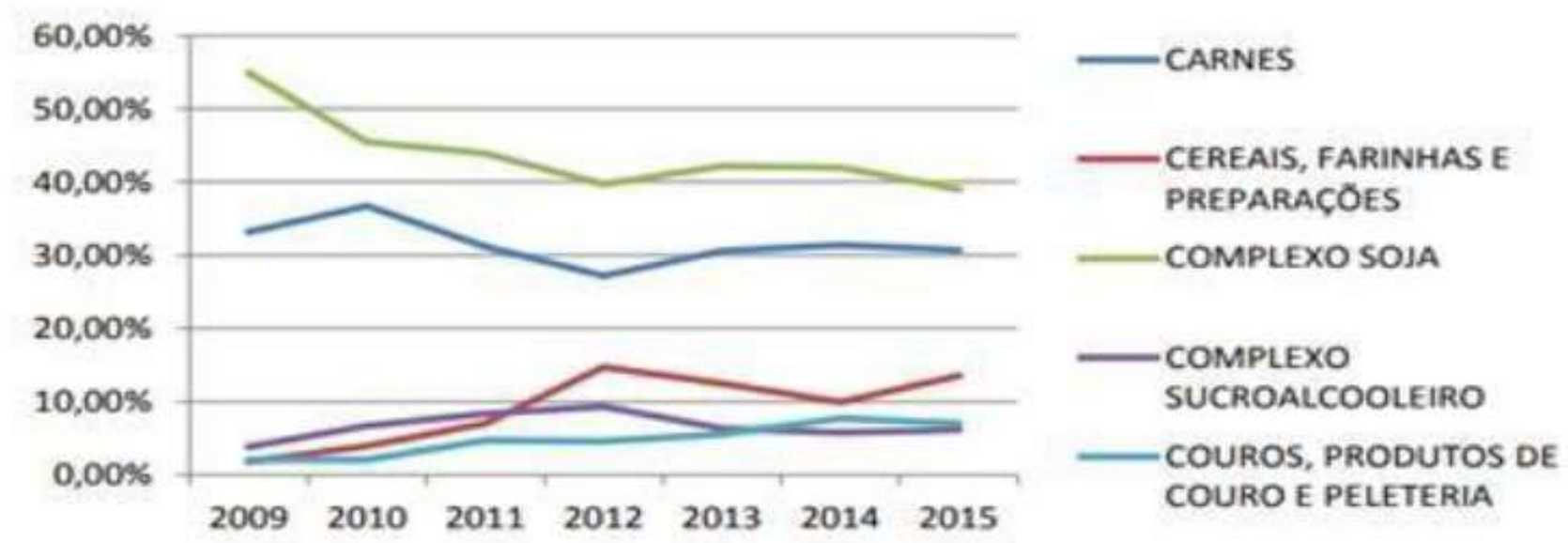

Figura 7: Estado de Goiás - Participação dos cinco maiores setores nas exportações do agronegócio (2009-2015).

Fonte: Agrostat - Estatísticas de Comércio Exterior do Agronegócio Brasileiro (2015). Elaboração: Instituto Mauro Borges (2017).

Na tabela 4 observamos que no ano de 2016 Goiás exportou quase US\$ 4,4 bilhões, sendo que o complexo da soja, carne, cana-de-açúcar e milho representaram quase $90 \%$ na participação deste total, refletindo a vantagem competitiva na comercialização destas commodities e a importância delas na performance de exportação do Estado: 
Tabela 4: Principais produtos exportados em Goiás - 2016.

\begin{tabular}{l|c|c}
\hline \multicolumn{1}{c|}{ Produtos } & Valor USS & $\begin{array}{c}\text { Part } \\
\mathbf{( \% )}\end{array}$ \\
\hline Complexo soja & 1.976 .809 .912 & $44,08 \%$ \\
\hline Carnes & 1.248 .221 .425 & $27,83 \%$ \\
\hline Complexo sucroalcooleiro & 384.068 .396 & $8,56 \%$ \\
\hline Cereais, farinhas e preparações & 383.107 .422 & $8,54 \%$ \\
\hline $\begin{array}{l}\text { Couros, produtos de couro e } \\
\text { peleteiras }\end{array}$ & 305.332 .037 & $6,81 \%$ \\
\hline Demais produtos & 187.562 .407 & $4,18 \%$ \\
\hline Total & $\mathbf{4 . 4 8 5 . 1 0 1 . 5 9 9}$ & $\mathbf{1 0 0}$ \\
\hline
\end{tabular}

Fonte: Agrostat - Estatísticas de Comércio Exterior do Agronegócio Brasileiro (2016). Elaboração própria.

Com os dados apresentados acima notamos uma forte relevância do complexo da soja, carne, canade-açúcar e do milho para o Estado. Sendo o complexo da Soja o que mais gera riquezas para Goiás principalmente devido a suas exportações, em seguida do complexo da carne, milho e cana-de-açúcar, que é voltado principalmente para o mercado interno com a produção de álcool e açúcar.

A criação de programas federais com o objetivo de descentralizar a indústria nacional e expandir o crescimento econômico, como o II PND, são medidas fundamentais que dão a infraestrutura necessária e viabilizam a implantação de novas indústrias e consequentemente o surgimento dos complexos agroindustriais em Goiás, além de programas estaduais que fomenta o crescimento e desconcentração industrial no próprio Estado, com programas como o PDEG, Polocentro e Proceder.

A Embrapa tem um papel fundamental neste processo de agroindustrialização, com pesquisas para correção do solo ácido e adaptação de sementes no Cerrado, que em conjunto com o aumento da tecnificação no campo em Goiás promovem saltos de produtividade e produção de soja, milho, carne e cana-de-açúcar. Este salto na produção é de fundamental importância para a balança comercial do Estado, já que a grande maioria das exportações de Goiás é de produtos agrícolas, e que gera crescimento no número de empregos a jusante, dentro a montante da atividade agrícola. 


\section{METODOLOGIA}

Para alcançar os objetivos do trabalho foi utilizada a coleta e a análise de dados históricos. A metodologia aplicada se resume a pesquisa documental com análise qualitativa dos dados. Análise de tabelas, gráficos, figuras ao considerar a variação percentual dos valores numa determinada série histórica.

De acordo com Lakatos e Marconi (2003), a pesquisa documental se baseia na coleta de informações que estão restritas aos documentos de fontes primárias, escritos ou não, que pertencem a arquivos públicos ou privados, estatísticas (censos), publicações parlamentares e administrativas, entre outros. Como fonte de dados, foram realizadas pesquisas bibliográficas em artigos, periódicos, livros, teses, dissertações, ao considerar a revisão da literatura com a teoria dos Complexos Agroindustriais, com o processo de modernização da agricultura, com destaque para os autores Kageyama, Graziano da Silva, Delgado e Muller. Além disso, foram coletados os dados secundários nos sites de órgãos como o Instituto Brasileiro de Geografia e Estatística (IBGE), Instituto Mauro Borges (IMB), Ministério da Indústria e Comércio Exterior e Serviços (MDIC) e Programa das Nações Unidas para o Desenvolvimento (PNUD) para analisar e avaliar as séries históricas de pesquisa da soja, milho e canade-açúcar em nível municipal, bem como os indicadores sociais como renda média, pessoas ocupadas e IDH Municipal.

A análise dos dados se concentrou na formação dos Complexos Agroindustriais em Goiás com os programas desenvolvimentistas do Polocentro, Prodecer, atrelados ao processo da Revolução Verde com a modernização da agricultura, principalmente as culturas da soja e do milho nas décadas de 60 e 70. A influência econômica dos Complexos Agroindustriais em Rio Verde e Quirinópolis foi analisada a partir dados históricos econômicos: de exportação, nível de mecanização com o número de tratores e defensivos, área plantada de soja, milho e cana-de-açúcar, Valor Adicionado Bruto da Agropecuária; e também dados socioeconômicos, como a renda média per capita, nível de emprego e IDH-M.

\section{A INFLUÊNCIA DOS COMPLEXOS AGROINDUSTRIAIS EM RIO VERDE E QUIRINÓPOLIS}

O objetivo deste capítulo é analisar a influência dos complexos agroindustriais nos municípios de Rio verde e Quirinópolis, que se situam na região Sudoeste e Sul de Goiás, com base na observação de dados históricos como exportações, utilização de maquinários agrícolas, área plantada, exportações e seus impactos no valor adicionado da agropecuária, renda per capita, geração de empregos e IDH 
destes municípios, que possuem entre si, diferentes tipos de atividades agropecuárias e agroindustriais.

\subsection{O MUNICÍPIO DE RIO VERDE}

A produção agrícola no Sudoeste Goiano, onde se localiza o município de Rio Verde (conforme Figura 8), passa por todo o processo de modernização do campo desde a década de 1960 com o uso de novas tecnologias e forte apoio estatal e se desenvolve principalmente no município de rio verdense, que é o principal produtor agrícola de Goiás (IMB, 2017).

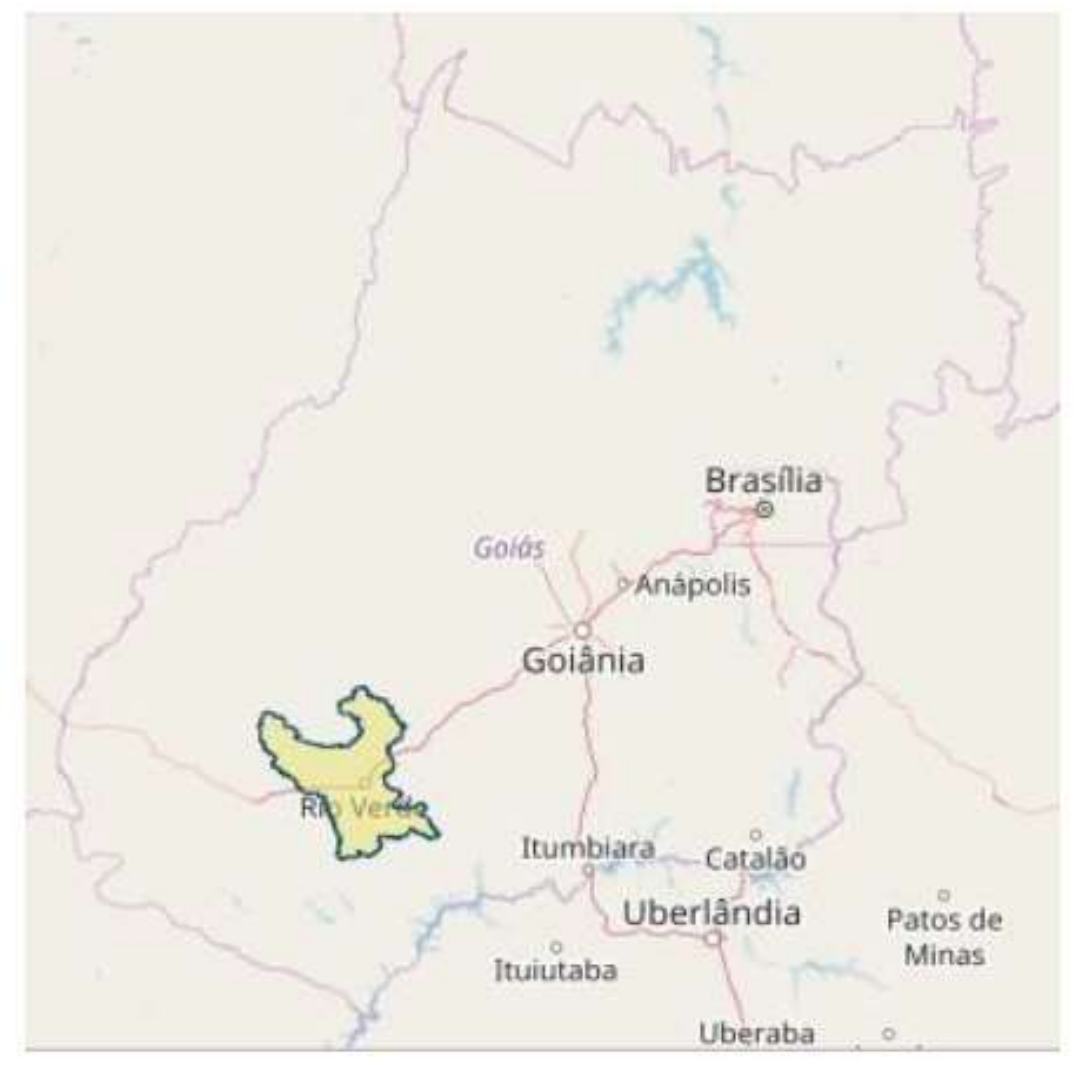

Figura 8: Mapa do Município de Rio Verde - GO.

Fonte: IBGE (2017).

De acordo com Santos e Silveira (2002, p. 128-129) "classificam o Sudoeste de Goiás como um front agrícola, que se moderniza e tecnifica nos anos de 1960 e 1970, tornando-se frente de expansão de oleaginosas e cereais (milho, arroz, algodão e soja)". Tal tecnificação na região possibilita então, segundo Prado (2017), a implantação na década de 1990 em Rio Verde uma grande empresa inserida à jusante com o complexo de carnes, a Perdigão, da Brasil Foods, tendo próximo a sua planta industrial a matéria-prima necessária para a produção da carne, bem como incentivos fiscais e financeiros dados pelo Estado. 
A cultura do milho, por exemplo, teve um expressivo crescimento no Sudoeste Goiano a partir dos anos 2000, devido principalmente ao surgimento da avicultura e suinocultura na região, já que o milho é uma matéria-prima fundamental na produção de rações. Esta integração da produção de milho com a produção da carne é reflexo da unificação agricultura-indústria, onde temos uma produção no campo moderna e a indústria no comando da direção, conforme definiu Graziano da Silva (1996). Prado (2017) ressalta que já no ano de 2010 tivemos no Sudoeste uma produção de milho duas vezes maior que a década anterior, que representou mais de $50 \%$ da produção total de Goiás, atingindo em 2015 uma produção 142\% maior que 2010, chegando a aproximadamente 62\% de participação na produção total de milho do Estado. Arrais (2006) nos diz que o crescimento do complexo de milho nesta microrregião está diretamente relacionado a vinda de empresas do complexo agroindustrial, como a Brasil Foods, que passam a demandar alimentação para suínos e aves.

Além do grande consumo local da produção de milho, Rio Verde tem uma considerável participação na exportação deste grão, e segundo Prado (2017), se enquadra entre os principais municípios exportadores de milho em Goiás, já que chega em 2016 com mais de 5\% de representatividade na exportação total do Estado, somando quase 22 milhões de dólares gerados pela venda do produto ao mercado externo. Analisando a Figura 9 abaixo podemos notar o expressivo crescimento de valor de exportação no período compreendido entre 1997 e 2016 para países como Egito, Vietnã, Coreia do Sul, África, Japão, Irã, Malásia, entre outros:

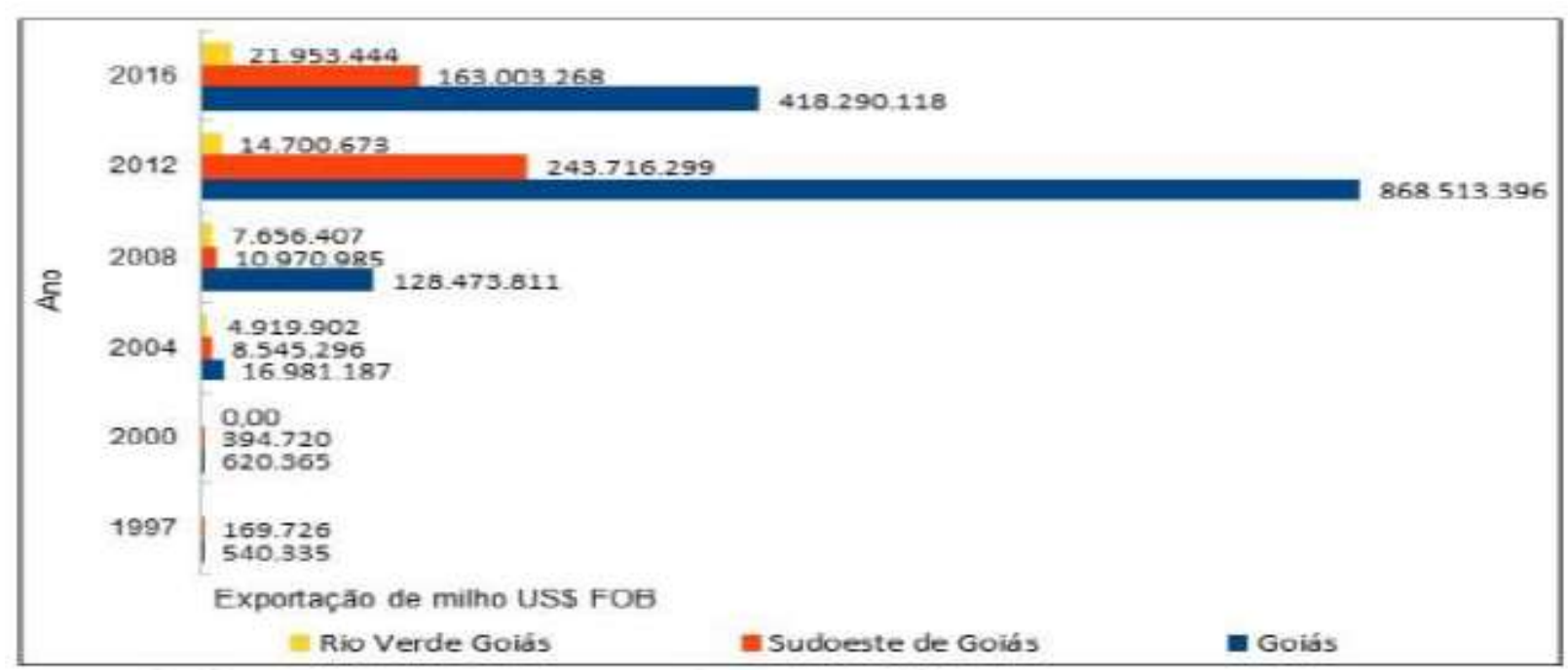

Figura 9: Exportação de milho: Sudoeste de Goiás, Rio Verde (1997 - 2016).

Fonte: Secretaria de Estado de Gestão e Planejamento (2016). Elaboração: Prado (2017). 
A cultura da soja no município de Rio Verde tem significativa representatividade na produção tanto no cenário estadual como no nacional, e é voltada principalmente para o mercado externo e industrial. De acordo com Borges (2006), a soja, juntamente com a cana-de- açúcar, são as principais culturas responsáveis pelo desenvolvimento dos Complexos Agroindustriais no Brasil, já que passam a demandar grande utilização de máquinas, fertilizantes e insumos em grande parte produzidos no exterior, tendo como papel chave neste processo o Estado com suas políticas fiscais de incentivo em conjunto com o capital privado na figura de bancos, que de acordo com Szmecsányi (1983) são instituições que passam a fazer parte desta relação em cadeia e complexa da agroindústria.

O complexo da soja passa a ter uma grande dependência tanto à montante quanto à jusante da produção após as inovações tecnológicas no campo a partir de 1965 e segundo Prado (2017), podemos analisar as exportações deste complexo subdivido em três seguimentos: a soja em grão ou triturada, o óleo de soja e o farelo. Na Figura 10 temos a evolução destes três seguimentos em Rio Verde, na região Sudoeste Goiano e no próprio Estado de Goiás em toneladas exportadas entre os anos de 1997 e 2016. Podemos analisar que em 1997 tínhamos no Estado a exportação de soja (em grão e triturada) e do farelo de soja, com a participação de Rio Verde em 13\% destas exportações. Já em 2016 observamos que esta participação tem um significativo crescimento, chegando a mais de $22 \%$ do total de exportações de soja do Estado, sendo que quase 90\% das exportações de óleo de soja de Goiás foi produzido no município rio- verdense:

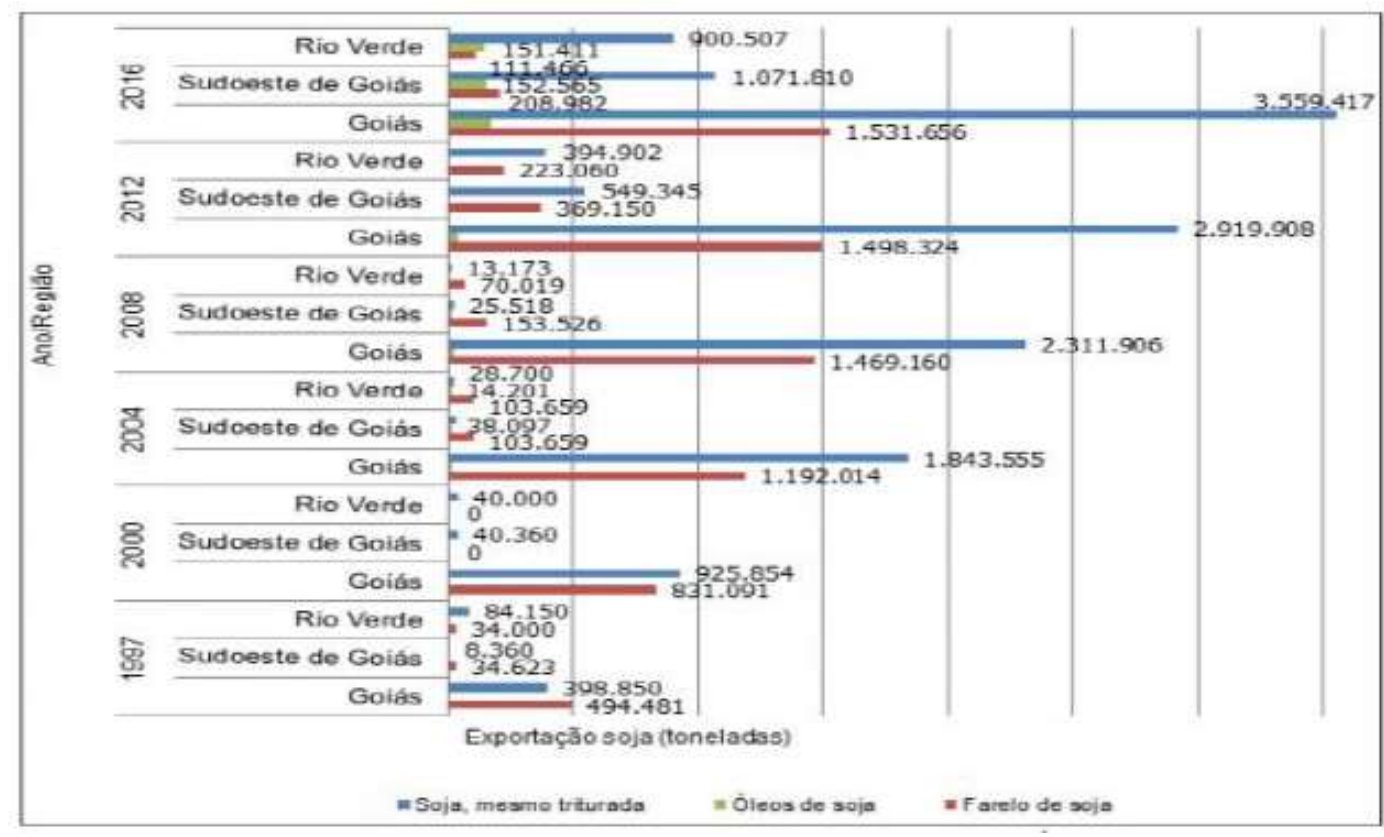

Figura 10: Exportação de soja (mesmo triturada), Farelo de soja e Óleos de soja, Goiás, Sudoeste de Goiás e Rio Verde (1997 - 2016). 
Fonte: Ministério da Indústria, Comércio Exterior e Serviços (2016). Elaboração: Prado (2017).

Prado (2017) afirma que tal crescimento na produção de grãos no município de Rio Verde e exportação, impactaram diretamente no crescimento da demanda por insumos e bens de capital à montante da produção, fruto das inovações tecnológicas, físico-químicas e mecânicas do século 20 que, de acordo Graziano da Silva (1996) estabeleceram um novo padrão agrícola no mundo. Fica evidente na Figura 11 a evolução da utilização de tratores, defensivos e fertilizantes por estabelecimentos agropecuários em Goiás, que reflete a tecnificação no campo e o aumento do controle humano sobre a natureza retratado por Graziano da Silva (1996), e a crescente representatividade da região Sudoeste neste processo, em que se localiza o município de Rio Verde. O papel dos defensivos e fertilizantes foi fundamental para proporcionar saltos de produtividade nas décadas de 70, 80 e 90, com redução da utilização nos anos 2000, porém o número de tratores utilizados só cresce em Rio Verde no período analisado, tendo uma participação de quase $22 \%$ do total operado no Estado no ano de 2006:

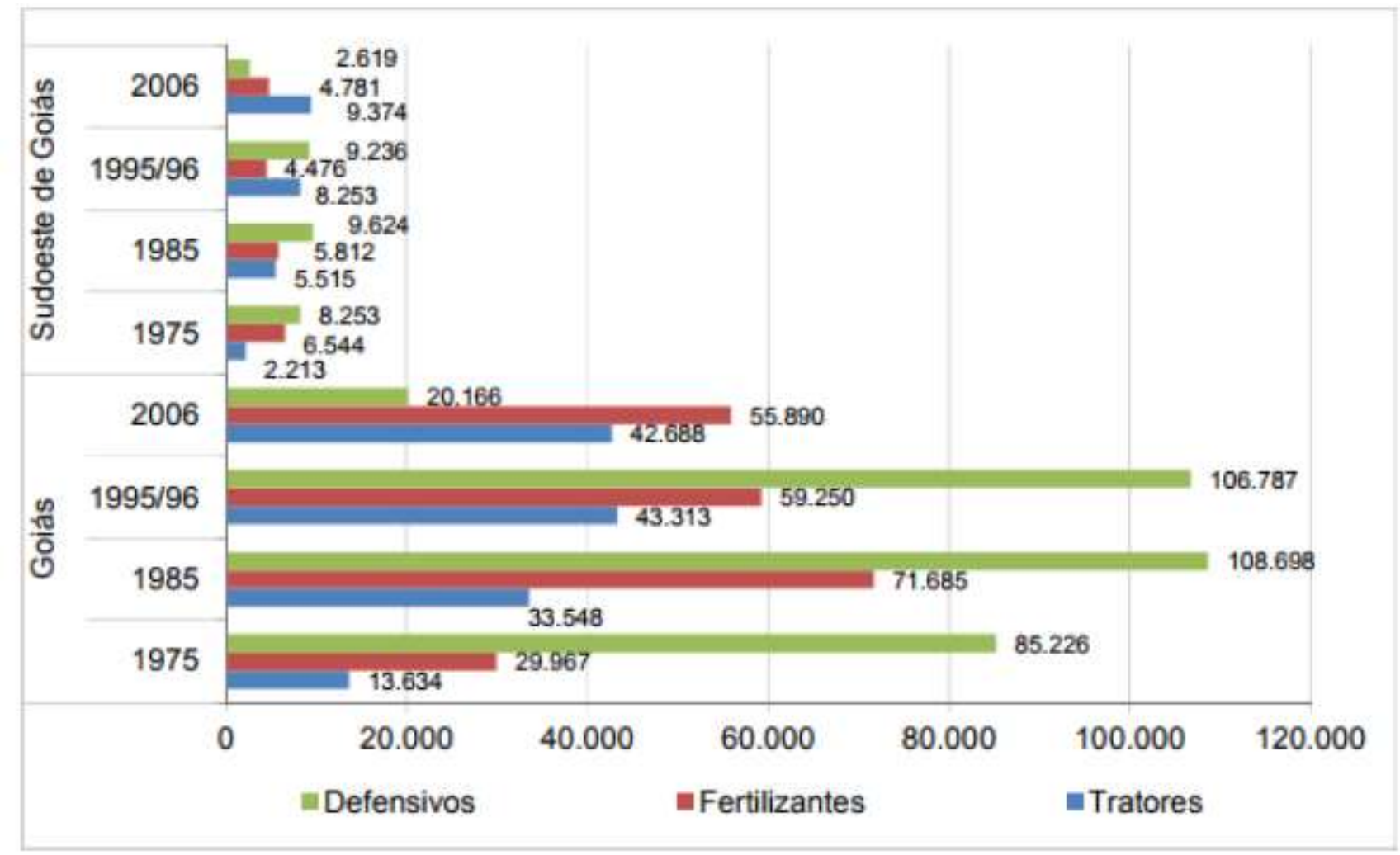

Figura 11: Goiás, Sudoeste de Goiás: número de tratores e utilização de Defensivos e Fertilizantes agrícolas por estabelecimentos agropecuários (1975 - 2006).

Fonte: IBGE (2016). Elaboração: Prado (2017).

Com a análise apresentada, fica claro a importância e protagonismo da cidade de Rio Verde no agronegócio goiano, principalmente pela geração de divisas com as exportações. Seus complexos de 
milho e soja estão totalmente integrados com a indústria tanto à montante, como defensivos químicos, fertilizantes e tratores, quanto à jusante, com o Complexo Agroindustrial da carne, que impactam diretamente na geração de empregos e renda para toda região.

\subsection{O MUNICÍPIO DE QUIRINÓPOLIS}

O município de Quirinópolis, localizado na região Sul do Estado de Goiás (conforme Figura 12), tem forte aptidão para o agronegócio e vem se desenvolvendo principalmente com a expansão do cultivo da cana-de-açúcar nos últimos anos. O sistema agroindustrial da cana, que também é fruto da integração agricultura-indústria apresentada por Graziano da Silva (1996), está voltado para a produção de álcool, açúcar, ração animal e biofertilizantes. Tem como protagonistas desta produção no município a Usina Boa Vista, que é uma associação entre o Grupo São Martinho e a Petrobras, e a usina São Francisco, do grupo paulista USJ e Cargill. Quirinópolis então, assim como Rio Verde está inserida no agronegócio goiano, porém seu Complexo Agroindustrial está relacionado principalmente a cultura da cana-de-açúcar, que possui características produtivas distintas do município rio verdense, inserido no complexo de grãos e carne.

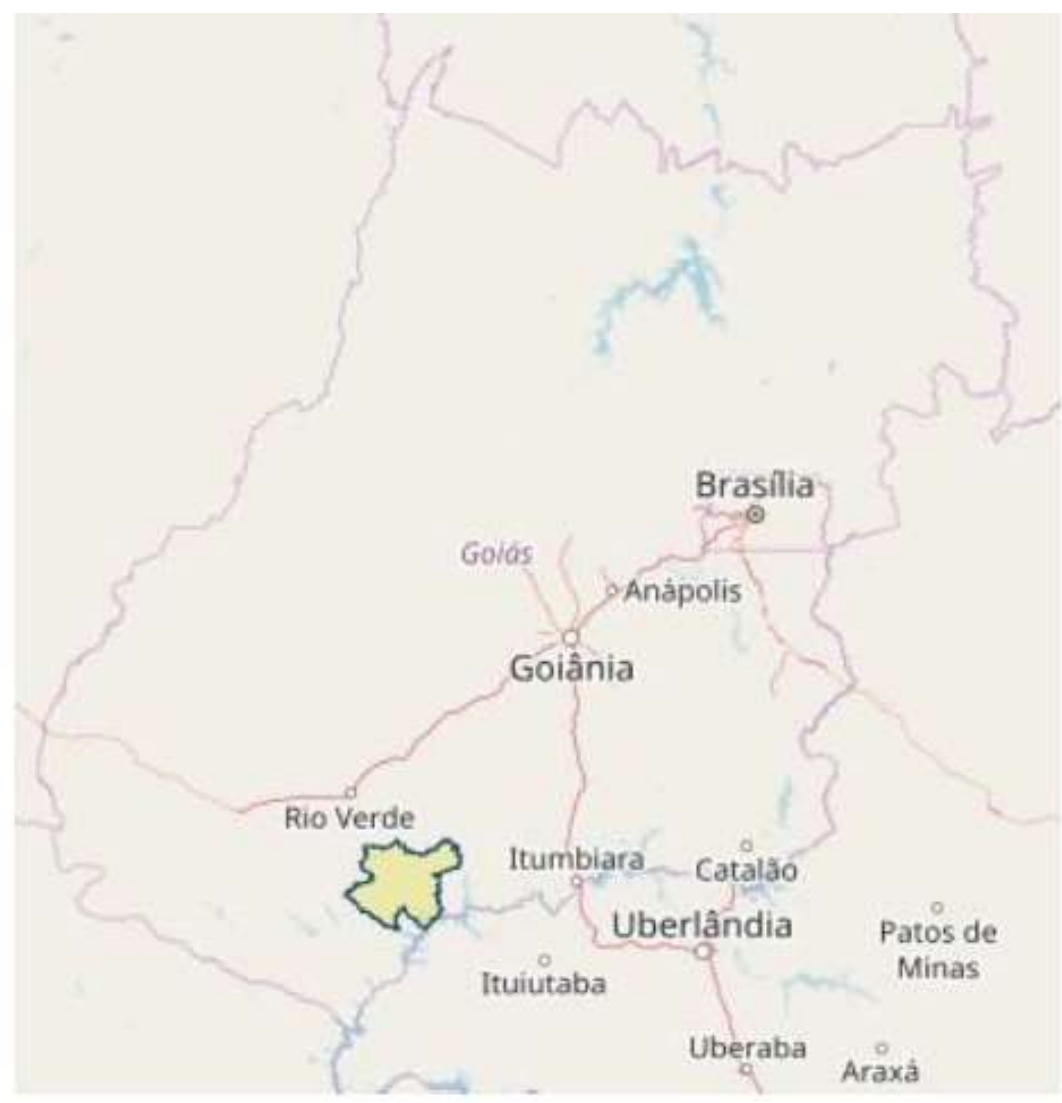

Figura 12: Mapa do Município de Quirinópolis - GO.

Fonte: IBGE (2017). 
Barbalho (2013) afirma que este crescimento é fruto principalmente de políticas públicas federais, destacando-se entre elas o Plano Nacional de Agroenergia - PNA (2006- 2011), com o intuito principalmente de elevar o consumo do álcool devido este ser uma fonte alternativa de energia menos poluente que a gasolina, em automóveis. O cultivo da cana-de- açúcar em Quirinópolis cresceu 1.225\% em área plantada no período de apenas uma década. O município, que até 2005 não cultivava a cana, planta uma área de 5.000 ha no ano de 2006, e chega a 66.247 ha plantados em 2016. De acordo com Barbalho (2013) tal crescimento se dá principalmente em substituição de áreas antes utilizadas para o cultivo de grãos e pastagens. Podemos observar tal crescimento do cultivo de cana em Quirinópolis na Figura 13 abaixo:

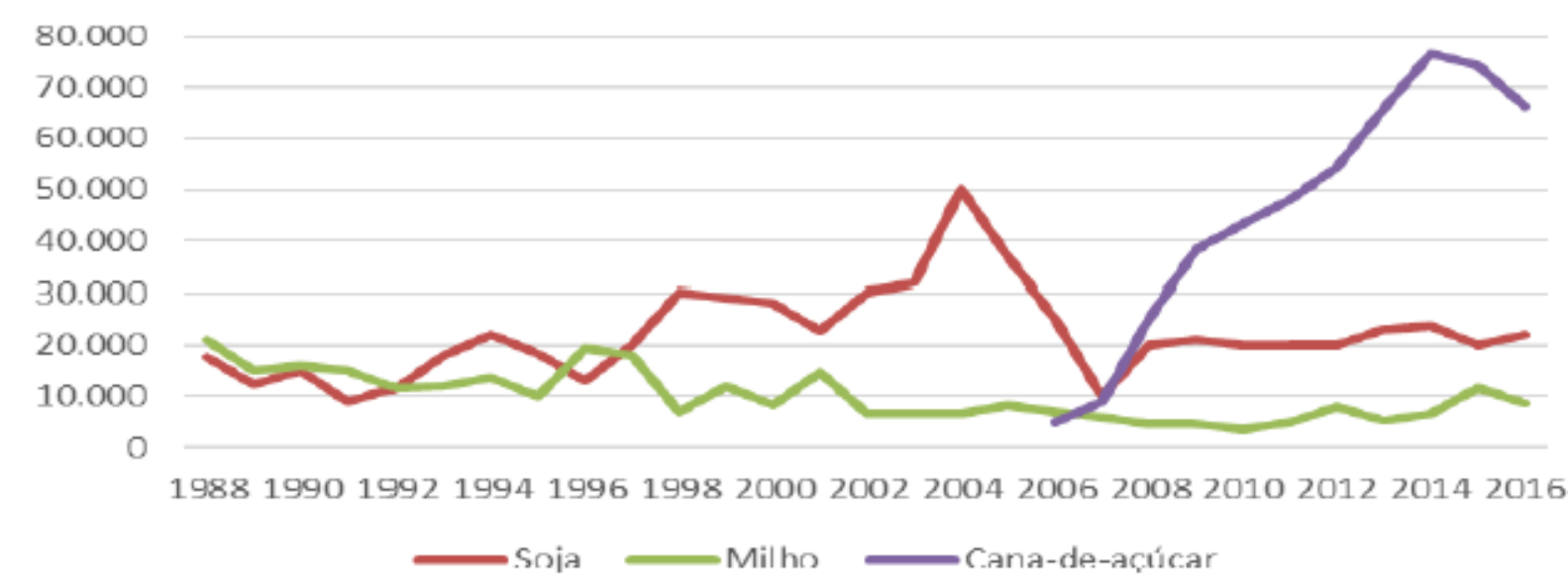

Figura 13: Área plantada de soja, milho e cana em Quirinópolis em hectares (1998 - 2016).

Fonte: IBGE (2016). Elaboração própria.

O município de Quirinópolis é destaque em termos de produção de cana, sendo o principal produtor da microrregião homônima, e principal produtor também do estado, de acordo com o IBGE (2016). Em segundo lugar temos o município de Mineiros, que pertence à microrregião Sudoeste, com 52 mil ha cultivados em 2016, e o terceiro lugar fica com Goiatuba, pertencente a microrregião Meia Ponte, que tem uma área plantada de 47.900 ha no mesmo ano. Com a Figura 14 podemos observar o expressivo crescimento da área plantada de 2006 a 2016 por microrregiões da mesorregião Sul de Goiás: 


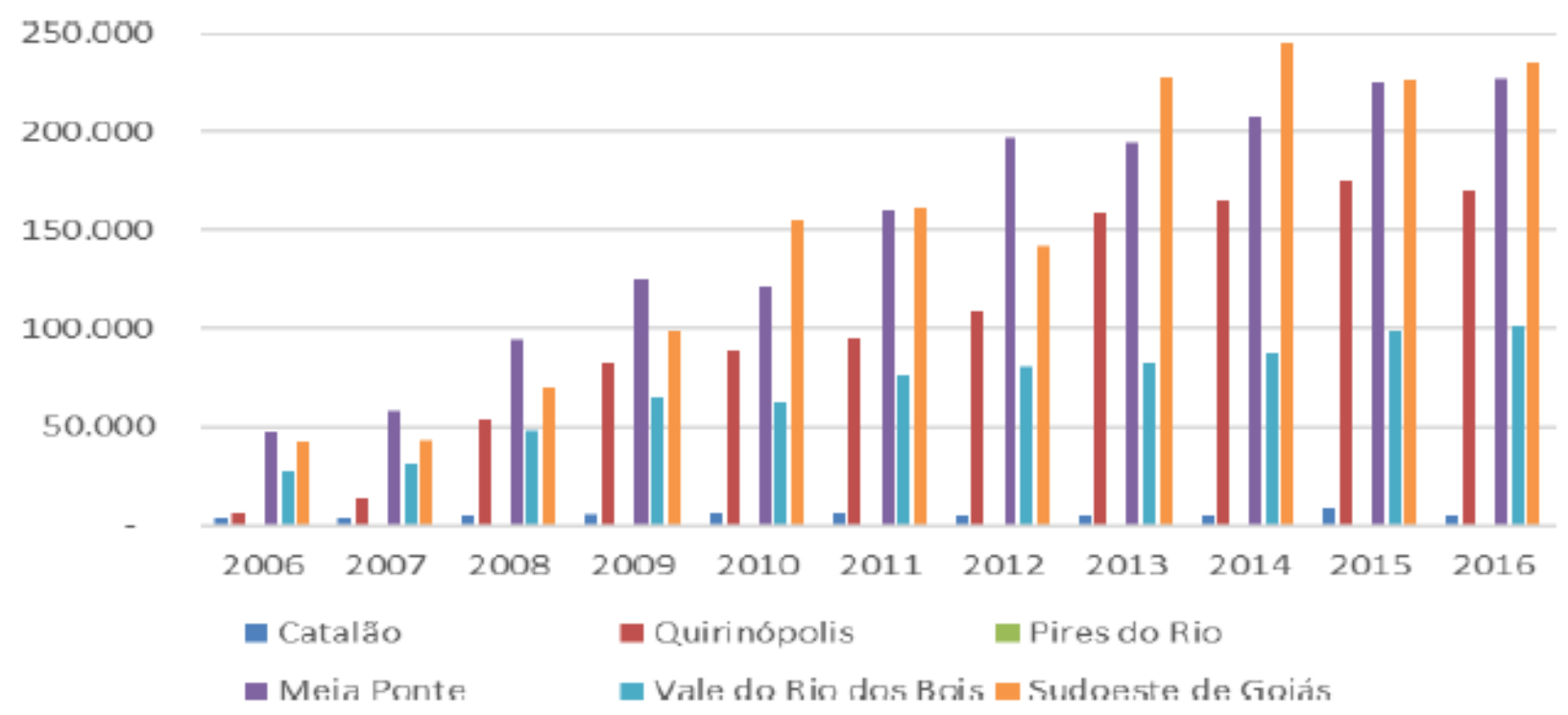

Figura 14: Área plantada com cana-de-açúcar por microrregião pertencente à mesorregião Sul de Goiás em hectares (2006 - 2016).

Fonte: IBGE (2016). Elaboração própria.

Com os dados apresentados, podemos observar que a cidade de Quirinópolis se encontra em franca expansão de área plantada e produção de cana-de-açúcar nos últimos 11 anos. Tal crescimento é reflexo da instalação de duas usinas instaladas no município com o intuito principal de suprir a necessidade de uma fonte alternativa de energia e, apesar de possuir características produtivas diferentes de Rio Verde, também vem gerando maior riqueza, emprego e renda para o município.

\subsection{VALOR ADICIONADO BRUTO DA AGROPECUÁRIA, RENDA MÉDIA PER CAPITA, EMPREGO E IDH-M}

O incremento na produção de grãos e carne em Rio Verde, que movimenta tanto o setor à montante quanto à jusante do processo produtivo reflete diretamente, e de forma positiva, no valor adicionado bruto da agropecuária no PIB do município. Segundo o IBGE, a cidade, que tinha um Valor Adicionado Bruto da agropecuária de R\$ 172 milhões em 1999, gera em 2014 mais de R\$ 1 bilhão, valor que representa $13,7 \%$ do total do PIB municipal de $\mathrm{R} \$$ 7,3 bilhões, conforme podemos observar na Figura 15. 


\section{Os Complexos Agroindustriais Nos Municípios De Rio Verde E Quirinópolis-Go}

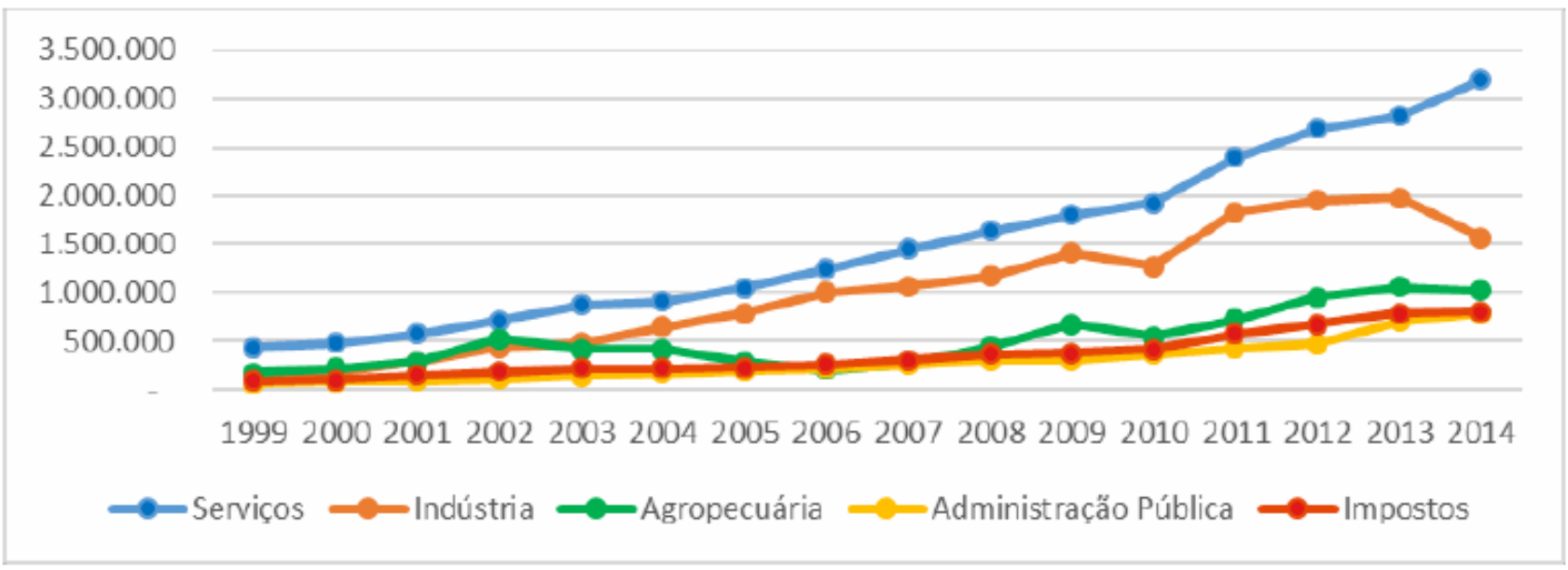

Figura 15: Valor Adicionado Bruto por atividade econômica no PIB de Rio Verde (1999 - 2014) $\mathrm{R} \$ 1.000$.

Fonte: IBGE (2014). Elaboração própria.

A evolução significativa na área plantada de cana-de-açúcar em Quirinópolis traz destaque para o município, já que em 2006 a produção desta cultura gerou um valor de R\$ 10,3 milhões, que em 2009 chega a mais de $\mathrm{R} \$ 55,6$ milhões segundo o IPEA (2014). Tal geração de valor impacta diretamente no crescimento do PIB municipal, que pode ser observado na Figura 16 abaixo. De acordo com o IBGE (2014), em 2006 o Valor Adicionado Bruto da agropecuária era de R\$ 68 milhões, em 2009 este valor tem um crescimento de $168 \%$ em relação ao ano de 2006 , com mais de $\mathrm{R} \$ 183$ milhões gerados e alcança em 2014 cerca de R\$ 223 milhões, acréscimo de 21\% em relação ao ano de 2009 e que representam $16,7 \%$ do total do PIB municipal de $\mathrm{R} \$ 1,3$ bilhões:

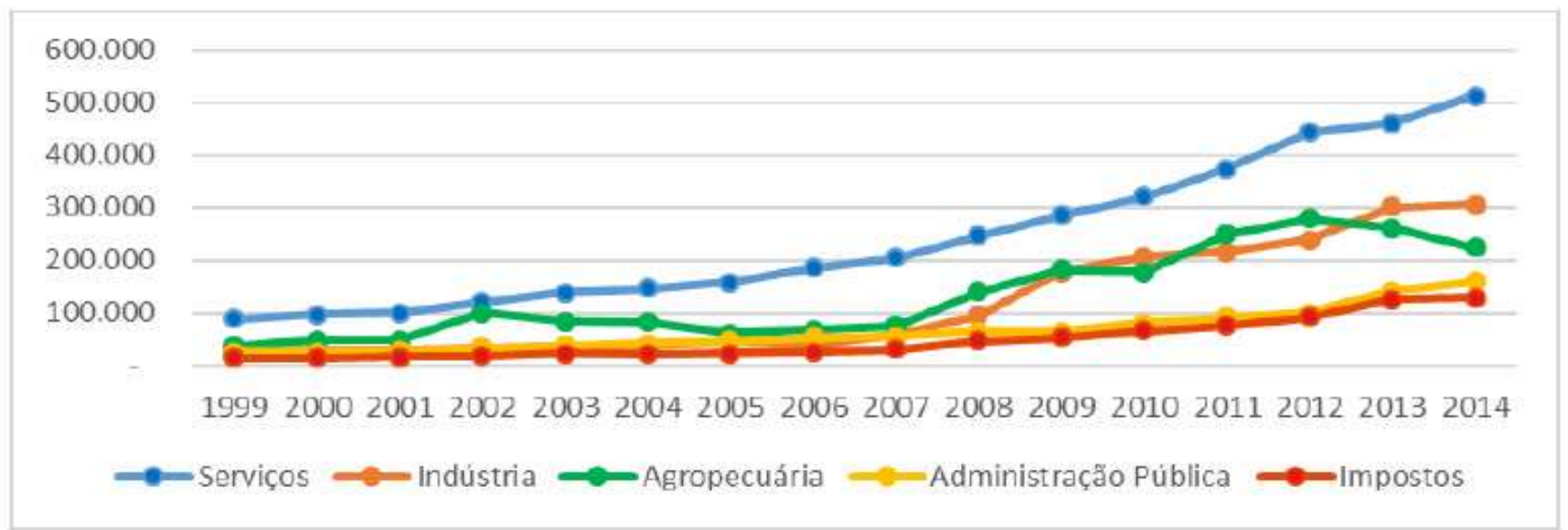

Figura 16: Valor Adicionado Bruto por atividade econômica no PIB de Quirinópolis (1999 - 2014) - R\$ 1.000 .

Fonte: IBGE (2014). Elaboração própria. 
Ao analisar a renda domiciliar per capita de Rio Verde e Quirinópolis, nota-se que em ambos os municípios há um expressivo crescimento de 1991 a 2010. Segundo o DATASUS (2014), Rio Verde com uma renda média de $\mathrm{R} \$$ 316,63 em 1991, em 2000 esta renda se eleva para $\mathrm{R} \$$ 670,77, com um crescimento de 111\%, e chega no ano de 2010 com uma renda média de $\mathrm{R} \$ \mathbf{8 8 4 , 1 6}$, mais um crescimento de quase 32\%. Quirinópolis, por sua vez, obteve um crescimento de $67 \%$ na renda média per capita de 1991 para 2000, chegando em 2010 com esta renda no valor de R\$ 743,58, que representa um crescimento de 55\% em relação aos anos 2000, conforme Figura 17:

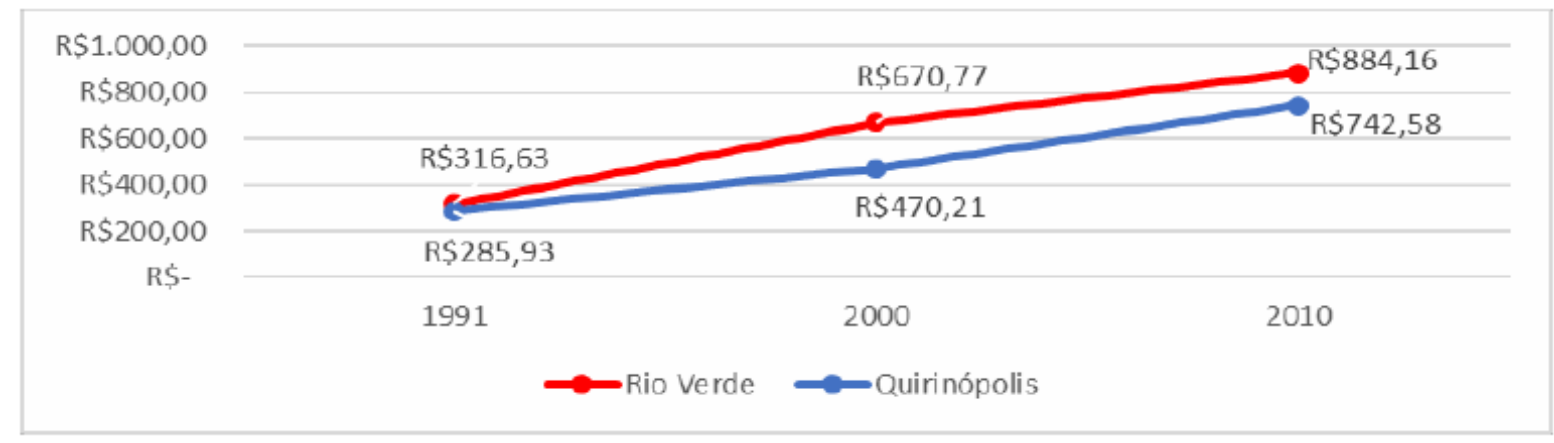

Figura 17: Renda Média Domiciliar per Capita de Rio Verde e Quirinópolis (1991 - 2010).

Fonte: Ministério da Saúde - DATASUS (2014). Elaboração própria.

Podemos observar que tanto em Rio Verde quanto em Quirinópolis, há também um crescimento significativo na quantidade de pessoas ocupadas. De acordo com o IBGE (2016), Rio Verde tem um crescimento de 52\% de 2006 para 2015 em número de empregos, saindo de

37.481 para 57.307 e o município de Quirinópolis, com um crescimento de mais de $88 \%$ no mesmo período analisado. Tal crescimento, que tem uma influência direta da atividade agropecuária, tanto para frente como para trás, conforme discutido por Muller (1989), é ilustrado na Figura 18 para os dois municípios:

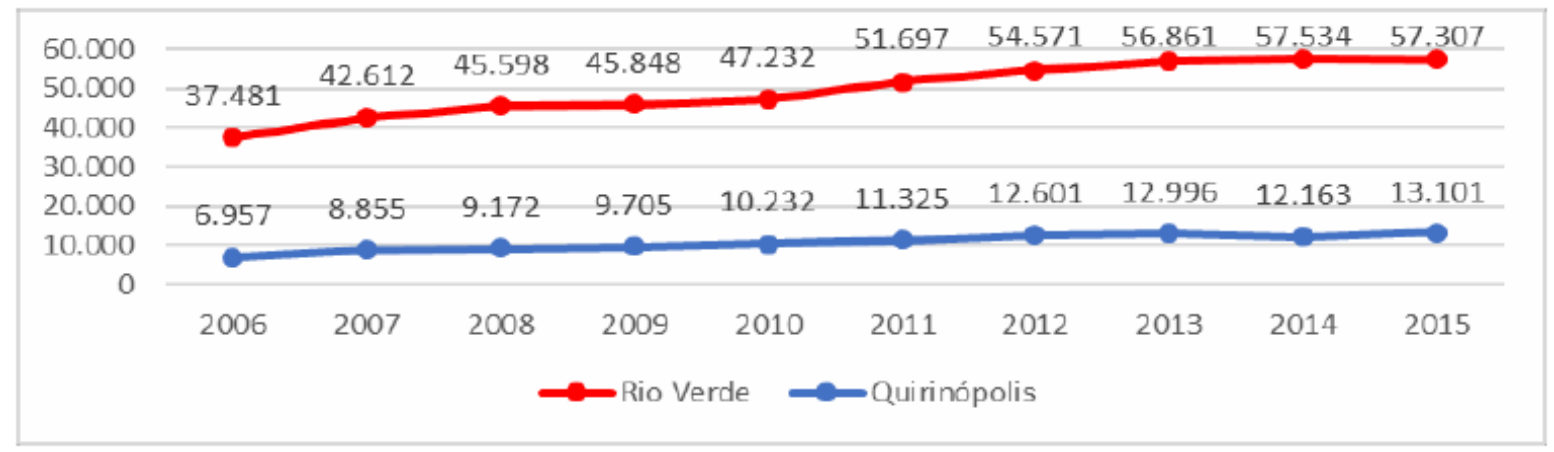

Figura 18: Pessoas ocupadas em Rio Verde e Quirinópolis (2006 - 2012).

Fonte: Cadastro Nacional de Empresas - Informações de Pessoal - IBGE (2016). Elaboração própria. 
Por fim, analisamos que o Índice de Desenvolvimento Humano dos municípios de Rio Verde e Quirinópolis cresceu de forma significativa nas últimas duas décadas. De acordo com o PNUD Programa das Nações unidas para o Desenvolvimento (2013), no ano de 1991 os municípios possuíam um IDH classificado como muito baixo, sendo que Rio verde ocupava a 24a posição no ranking estadual e Quirinópolis o 43ㅇ lugar. Em 2000, podemos observar que este índice saiu de muito baixo para médio em ambos os municípios, com Rio Verde subindo para o 13익 lugar em Goiás e Quirinópolis para 34ㅇ․ Já no ano de 2010 temos mais salto na faixa de índice desenvolvimento, com o IDH-M dos dois municípios classificados como alto pelo PNUD, Rio Verde subindo para a 6ạ e Quirinópolis para a 19ạ posição no ranking estadual. Podemos observar que a diferença de IDH-M entre os dois municípios se diminui de 1991 para 2010, conforme Figura 19:

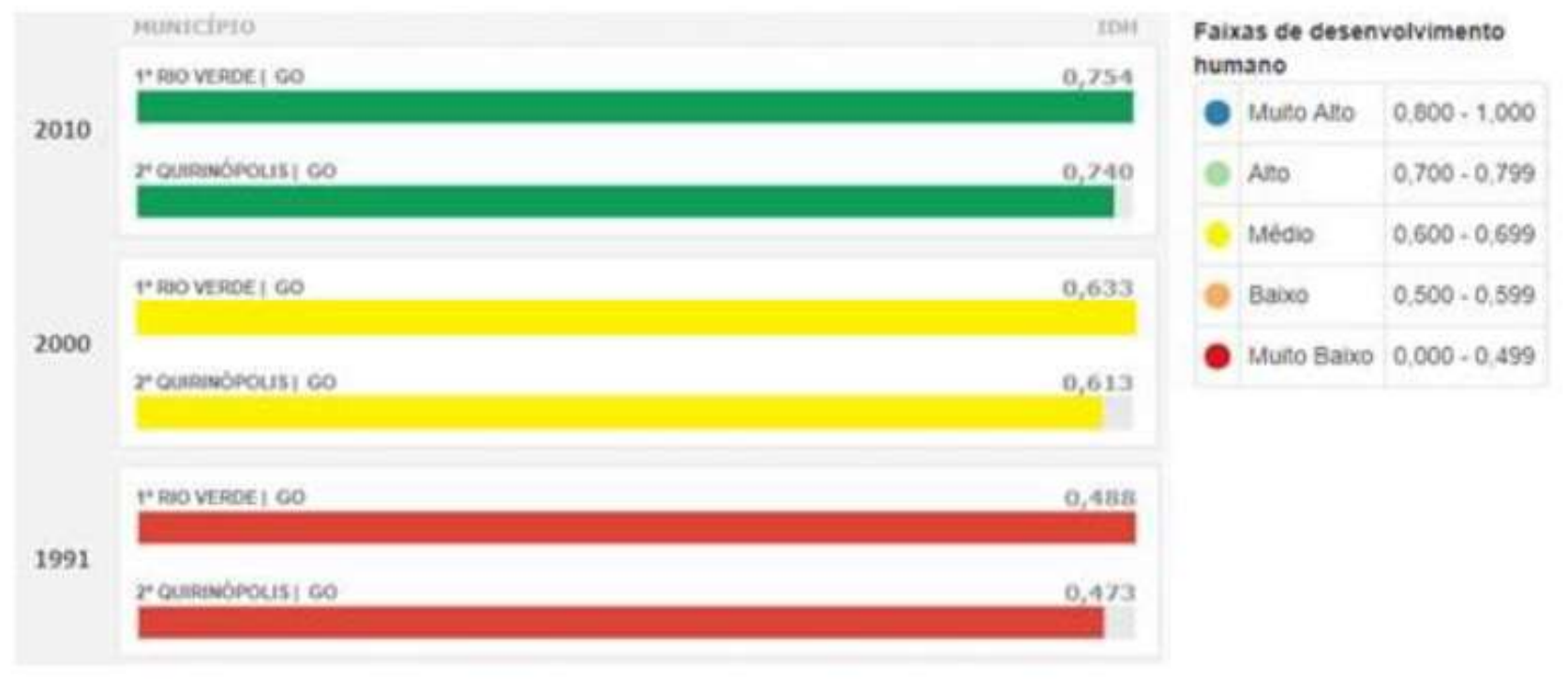

Figura 19: Índice de Desenvolvimento Humano Municipal (1991 - 2010).

Fonte: PNUD - Programa das Nações Unidas para o Desenvolvimento (2013). Elaboração própria.

O considerável crescimento da agropecuária nos dois municípios analisados, trazem impactos positivos diretos dentro e fora da cadeia agrícola estabelecida que, de acordo com Delgado (1985), tem como resultado bens de produção industrial em substituição aos "produtos naturais" no campo. Tais bens de produção são distintos e consequentemente dispõem de diferentes complexos agroindustriais envolvidos em Rio Verde e Quirinópolis, mas que por sua vez desencadeiam bons resultados para os aspectos econômicos, como o PIB, e aspectos socioeconômicos, como renda per capita, emprego e IDH de ambos os municípios. 
O crescimento do emprego em toda cadeia produtiva, tanto à montante, quanto à jusante da prática agropecuária se deve em grande parte devido a movimentação e crescimento destes complexos na região, que influenciam também de forma indireta na elevação da renda como um todo, tendo como consequência a melhoria na qualidade de vida municipal, refletida no crescimento do IDH, índice que mede a longevidade, renda média e educação da população.

Analisando os dados apresentados, podemos inferir que o crescimento dos complexos agroindustriais de milho, soja e carne vem trazendo ano após ano resultados positivos para o município de Rio Verde, gerando maiores riquezas, aumentando a renda de sua população, bem como aumentando o número de empregos e o IDH municipal. Em Quirinópolis, o recente complexo da cana-de-açúcar instaurado não traz resultado diferente, e apesar de ter um valor agregado da agropecuária 4 vezes menor que em Rio Verde, apresenta maiores crescimentos em termos de renda per capita, empregos e IDH no período observado. Portanto, as influências dos complexos agroindustriais são de grande relevância para a economia destes municípios e refletem ganhos sociais para as regiões em que estão inseridos e para o Estado como um todo.

\section{CONSIDERAÇÕES FINAIS}

O objetivo geral deste livro concentrou-se na análise da influência dos diferentes complexos agroindustriais situados em Rio Verde e Quirinópolis, observando o crescimento da produção e da geração de valor da agropecuária em nível municipal, com a hipótese de que esta influência é positiva no âmbito social, independentemente da atividade agrícola principal e do complexo agroindustrial instalado.

Dada a importância histórica da agropecuária no Brasil, com este trabalho ampliamos nossa visão sobre esta prática e entendemos melhor sua formação, desdobramentos e complexidade, que nos dá percepção do quão importante é a agropecuária nos dois municípios goianos analisados, atividade esta que continuará desempenhando um papel crucial no crescimento econômico e desenvolvimento social rio verdense e quirinopolino.

Constatou-se que no estado de Goiás, a agroindústria é incentivada com planos governamentais de âmbito nacional, como o II Plano de Integração Nacional (II PND), que tinha por objetivo a descentralização industrial da região Sudeste, com a expansão da malha rodoviária para outras regiões, e assim ser possível dar continuidade as altas taxas de crescimento econômico vivenciadas no Milagre Econômico da década de 1960/70. Já na década de 70 temos também a criação da EMBRAPA, 
que é responsável por elevar a tecnificação e aumentar a produtividade da agropecuária goiana. Em âmbito Estadual, o Plano de Desenvolvimento de Goiás (PDEG) cria a Secretaria de Indústria e Comércio e o Banco do Estado de Goiás a fim de fomentar o desenvolvimento industrial no estado a partir de 1961. Além deste, temos o PRODOESTE, o POLOCENTRO e PROCEDER, que também foram essenciais para o crescimento da malha rodoviária no estado e de atrair investimentos privados com incentivos fiscais à grandes agroindústrias e reflete o crescimento da utilização de tratores, fertilizantes e defensivos nos estabelecimentos agrícolas de Goiás.

A criação da Cooperativa COMIGO em 1975 é um marco para o crescimento do complexo da soja e do milho no Estado, principalmente na região Sudoeste de Goiás, que facilita posteriormente a implantação da Perdigão com o complexo da carne, gerando milhares de novos empregos no município de Rio Verde e região, que se torna extremamente importante na geração de divisas no Estado.

Posteriormente ao cultivo de soja e do milho, temos inserção do cultivo de cana-de- açúcar para biorrefinarias de álcool e açúcar no estado, incentivadas pelo Programa Nacional de Álcool, com o objetivo de substituir a gasolina por ser uma fonte de energia renovável e menos poluente. Como protagonista desde crescimento nos anos 2000, temos o município de Quirinópolis, localizado na região Sul do estado. Com a implantação de duas grandes usinas processadoras de cana, o município se desponta na expansão de área plantada de cana, principalmente com a substituição de áreas anteriormente com cultivo de cereais, que também incentiva o crescimento da indústria tanto à montante quanto à jusante do processo.

Ao observar as séries históricas de valor adicionado bruto da agropecuária, podemos inferir que os complexos agroindustriais estabelecidos em Rio Verde e Quirinópolis influenciam direta e indiretamente de forma positiva na geração de riquezas, independente do complexo agroindustrial predominante (milho, soja, carne ou cana-de-açúcar), bem como no expressivo crescimento da renda média per capita, do número de pessoas ocupadas em ambos municípios e crescimento no Índice de Desenvolvimento Humano do município. Complexos estes que possuem relevante contribuição para o agronegócio como um todo, com a produção de alimentos e energia, fundamentais no crescimento do estado de Goiás e do Brasil, além da grande relevância a nível mundial na produção de alimentos.

No município de Rio Verde, já havia o cultivo do milho e da soja antes mesmo da instalação da COMIGO na década de 70, mas que ganha novas forças a partir de suas estruturas que dão suporte ao cultivo, armazenamento e comercialização destes grãos. Esta base agrícola de grãos instaurada na região, 
juntamente com incentivos fiscais atraíram a agroindústria da carne para o município rio verdense e propulsionou novamente o cultivo do milho e da soja, gerando novos empregos e renda, além de ser responsável por contribuir para o crescimento do IDH municipal. O excedente desta produção é exportado, e contribui significativamente para uma balança comercial favorável no Estado, que possui $80 \%$ de suas exportações relacionadas a produtos agropecuários.

O município de Quirinópolis, apesar de gerar um valor adicionado bruto da agropecuária menor, possui uma maior participação deste na composição total do PIB municipal e tem com o recémformado complexo da cana-de-açúcar um forte aliado na geração empregos, à montante e à jusante, e elevação da renda média municipal, que estão crescendo acima do que cresce na cidade rio verdense, bem como no crescimento do IDH municipal, que vem se aproximando ao IDH do município de Rio Verde no período analisado.

Devido a limitação do trabalho, infelizmente não foram feitas comparações entre as micro e mesorregiões de Goiás, mas a influência dos complexos agroindustriais pôde ser bem analisada em nível municipal, e fica claro a evidência de que, com o apoio do estado e demais instituições, todos os diferentes complexos observados tem significativo influência econômica com a geração de riquezas e impactos sociais que refletem uma melhoria de vida da população situada em Rio Verde e Quirinópolis.

Fica como sugestão para próximas pesquisas, a observação destes complexos agroindustriais em outros municípios agrícolas, com comparações entre as microrregiões e mesorregiões que compõem de Goiás, bem como a análise dos demais complexos agroindustriais, com diferentes atividades agrícolas existentes no estado. 


\section{REFERÊNCIAS}

ARAUJO, N.B; W EDEKIN, I; PINAZZA, L. Complexo agroindustrial - O "Agribusiness Brasileiro", Agroceres, São Paulo, 1990.

ARRAIS, Tadeu Alencar. A região como arena política. Goiânia: Vieira, 2007.

ARRAIS, Tadeu Alencar. Geografia Contemporânea de Goiás. Goiânia: Ed. Vieira, 2006.

ARRIEL, Marcos Fernando. A dinâmica produtiva e espacial da indústria goiana. 2017. 209 f. Tese (Doutorado em Geografia) - Instituto de Estudos Socioambientais, Universidade Federal de Goiás, Goiânia, 2017.

BARBALHO, Maria G. da S. A expansão da área de cultivo de cana-de-açúcar na região sul do estado de Goiás de 2001 a 2011. Revista Brasileira de Ciências Ambientais, N. 29, p. 1- 13, set. 2013.

BORGES, Ronan Eustáquio. Complexos agroindustriais e desenvolvimento regional: o caso do Sudoeste de Goiás. In. Anais do XXI ENCONTRO NACIONAL DE GEOGRAFIA AGRÁRIA, 2012, Uberlândia, 2012.

BORGES, Ronan Eustáquio. No meio da soja, o brilho dos telhados: a implantação da Perdigão em Rio Verde - GO, transformações e impactos socioeconômicos e espaciais. 2006. 229 f. Tese (Doutorado em Geografia) - Universidade Estadual Paulista "Júlio de Mesquita Filho", Rio Claro - SP, 2006.

BRUM, Argemiro J.A. Modernização da Agricultura: trigo e soja. Petrópolis: Vozes; ljuí: FIDENE, p. 3189, 1988.

CASTRO, Ana C. et al. Evolução recente e situação atual da agricultura brasileira. Síntese das transformações. Brasília: Binagri, 1979.

CEPEA/ESALQ. PIB do agronegócio brasileiro. Piracicaba, 2017. Disponível em:

<http://www.cepea.esalq.usp.br/br/pib-do-agronegocio-brasileiro.aspx>. Acesso em 16 jun. 2017.

CNA. Agropecuária supera obstáculos e segue liderando a economia brasileira em 2016. Brasília, 2016. Disponível em: <http://www.cnabrasil.org.br/noticias/agropecuaria-supera- obstaculos-e-segueliderando-economia-brasileira-em-2016>. Acesso em:16 jun. 2017.

GRAZIANO DA SILVA, J. A nova Dinâmica da Agricultura Brasileira. Campinas: UNICAMP,1996.

GRAZIANO DA SILVA, J. Progresso técnico e relações de trabalho na agricultura. São Paulo: HUCITEC, 1981. 210 p. (Economia \& Planejamento. Série "Teses e Pesquisas").

GREMAUD, Amaury Patrick; VASCONCELLOS, Marco Antonio Sandoval de; TONETO JUNIOR, Rudinei. Economia Brasileira Contemporânea. 4. ed. São Paulo: Atlas, 2002.

HOLANDA, A. B. Dicionário Aurélio da Língua Portuguesa. 2. ed. Rio de Janeiro: Editora Nova Fronteira, 1986, p. 440. 
IBGE - Instituto Brasileiro de Geografia e Estatística. Censos agropecuários de 1975 a 2006. Disponível em: <https://sidra.ibge.gov.br/pesquisa/censo-agropecuario/censo- agropecuario-2006/segundaapuracao>. Acesso em: $10 \mathrm{dez} .2017$.

IBGE - Instituto Brasileiro de Geografia e Estatística. Cidades. Disponível em: < https://cidades.ibge.gov.br/xtras/uf.php?lang=\&coduf=52\&search=goias>. Acesso em: 12 nov. 2017.

IBGE - Instituto Brasileiro de Geografia e Estatística. Cadastro nacional de empresas - Informação de pessoal. Disponível em:

<https://sidra.ibge.gov.br/pesquisa/cempre/quadros/brasil/2015 >. Acesso em: 11 nov. 2017.

IBGE - Instituto Brasileiro de Geografia e Estatística. População residente em Goiás. Disponível em: <https://cidades.ibge.gov.br/painel/populacao.php?codmun=520870>. Acesso em 10 dez. 2017.

IBGE - Instituto Brasileiro de Geografia e Estatística. Produção Agrícola Municipal.

Disponível em: <https://sidra.ibge.gov.br/pesquisa/pam/tabelas>. Acesso em: 11 dez. 2017.

IBGE - Instituto Brasileiro de Geografia e Estatística. VAB por setor de atividade. Disponível em: <ftp://ftp.ibge.gov.br/Pib_Municipios/2014/ >. Acesso em: 11 nov. 2017.

IMB - Instituto Mauro Borges. Composição do PIB Goiano. Goiânia, 2017. Disponível em:

<http://www.imb.go.gov.br/visaogeral/index.html>. Acesso em 16 jun. 2017.

IMB - Instituto Mauro Borges. Produção e preço da canade-açúcar em Goiás. Conjuntura econômica goiana, n. 23, p. 1-12, 2012. Disponível em:

<http://www.imb.go.gov.br/pub/conj/conj23/artigo04.pdf>. Acesso em: 11 nov. 2017.

JOHNSTON, B.F.; MELLOR, J.W. The role of agriculture in economic development. American Economic Review, vol. 51, n.4, p. 566-93, 1961.

KAGEYAMA, Angela (coord.). O novo padrão agrícola brasileiro: do Complexo Rural aos Complexos Agroindustriais. Campinas, s.n. 1987.

KAUTSKY, K. A questão agrária. 3 ed. São Paulo: Proposta Editorial, 1980. 362 p.

LAKATOS, Eva Maria; MARCONI, Marina de Andrade. Fundamentos de metodologia científica. 5. ed. São Paulo: Atlas, 2003.

LIMA, Pedro Ramos. A Evolução do agronegócio em Goiás: As transformações e consequências sociais de 1970 a 2010. 2011. 131 f. Dissertação (Mestrado em Desenvolvimento e Planejamento Territorial) - Departamento de Ciências Econômicas, Pontifícia Universidade Católica de Goiás, Goiânia, 2011.

LUCENA, Romina B. de; SOUZA, Nali de J. As funções da agricultura no desenvolvimento econômico. Estudos do CEPE, Santa Cruz do Sul, n. 9/10, p. 127-148, jan./dez. 1999.

MAPA - Ministério da Agricultura, Pecuária e Abastecimento. Revista de Política Agrícola. 
Brasília, №3, Jul./Ago./Set. 2005, p.5. Disponível em:

<http://www.agricultura.gov.br/assuntos/politica-agricola/todas-publicacoes-de-politicaagricola/revista-de-politica-agricola>. Acesso em 16 jun. 2017.

MAPA - Ministério da Agricultura, Pecuária e Abastecimento. AGROSTAT - Estatísticas de Comércio Exterior do Agronegócio Brasileiro. Disponível em:

<http://indicadores.agricultura.gov.br/agrostat/index.htm>. Acesso em: 10 dez. 2017.

Ministério da Saúde - DATASUS. Renda média domiciliar per capita. Disponível em: < http://tabnet.datasus.gov.br/cgi/deftohtm.exe?ibge/censo/cnv/rendabr.def>. Acesso em: 11 nov. 2017.

MÜLLER, Geraldo. As relações micro-macro e indústria agroalimentar: o poder econômico e a pesquisa em ciências sociais. Rascunho. Araraquara, n. 1, p. 1-53, jun. 1989.

OECD/Food and Agriculture Organization of the United Nations (2015), OECD-FAO Agricultural Outlook 2015, OECD, Paris, 2015. Disponível em: < http://www.fao.org/3/a- i4738e.pdf >. Acesso em: 11 nov. 2017.

PNUD - Programa das Nações Unidas para o Desenvolvimento - IDH por município e estado. Disponível em: <http://www.atlasbrasil.org.br/2013/download/>. Acesso em: 28 nov. 2017.

PRADO, Raquel M. A formação dos complexos agroindustriais: a BRF e o crescimento de Rio Verde em Goiás. 2017. 179 f. Dissertação (Mestrado em Desenvolvimento e Planejamento Territorial) Coordenação de Pós-Graduação Strictu Sensu, Pontifícia Universidade Católica de Goiás, Goiânia, 2017.

PRESSE, FRANCE. População mundial chegará aos 10 bilhões em 2050, segundo estudo. Rio de Janeiro, 2015. Disponível em:

<http://g1.globo.com/mundo/noticia/2015/09/populacao-mundial-chegara-aos-10-bilhoes-em2050-segundo-estudo.html>. Acesso em: 16 jun. 2017.

RODRIGUES SALGADO, TATHIANA. O processo histórico de regionalização administrativa do Estado de Goiás: experiências de 1956 a 1989. Boletim Goiano de Geografia, v. 32, n. 1, p. 105-119, jan./jun., 2012.

SANTOS; SILVEIRA, Maria Laura. O Brasil: território e sociedade no início do séc. XXI. 4a ed., Rio de Janeiro: Record, 2002. p. 1-140.

SOUZA, Nali de J. Desenvolvimento Econômico. 4 ed. São Paulo, Atlas 1999.

STREETER, D. H.; SONKA, S. T.; HUDSON, M. A. Information technology, coordination, and competitiveness in the food and agribusiness sector. American Journal of Agricultural Economics, $v$. 73, n. 5, p. 1465-71, 1991.

SZMRECSÁNYI, T. Nota sobre o complexo agroindustrial e a industrialização da agricultura. Revista de Economia Política, São Paulo, v. 3, n. 2, p. 141 - 144, abr./maio 1983. 